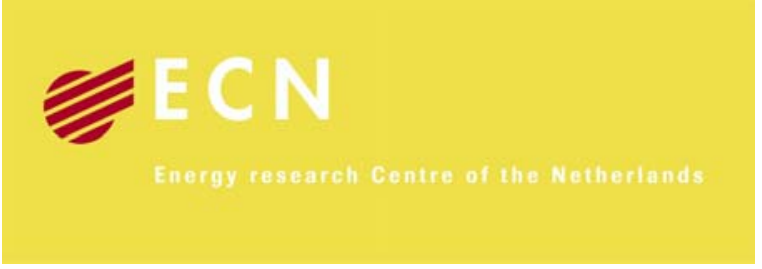

\title{
A consistent geochemical modelling approach for the leaching and reactive transport of major and trace elements in MSWI bottom ash
}

\author{
J.J. Dijkstra \\ J.C.L. Meeussen \\ H.A. van der Sloot \\ R.N.J. Comans
}

Published in Applied Geochemistry 23 (2008) 1544-1562 


\title{
A consistent geochemical modelling approach for the leaching and reactive transport of major and trace elements in MSWI bottom ash
}

\author{
Joris J. Dijkstra ${ }^{\mathrm{a}}$, Johannes C.L. Meeussen ${ }^{\mathrm{a}}$, Hans A. Van der Sloot ${ }^{\mathrm{a}}$, \\ Rob N.J. Comans ${ }^{a, b, *}$

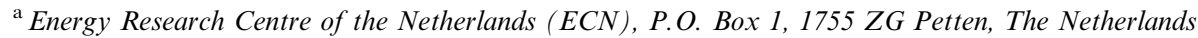 \\ ${ }^{\mathrm{b}}$ Wageningen University, Department of Soil Quality, P.O. Box 8005, 6700 EC Wageningen, The Netherlands
}

Received 3 November 2006; accepted 9 December 2007

Editorial handling by R. Fuge

Available online 9 February 2008

\begin{abstract}
To improve the long-term environmental risk assessment of waste applications, a predictive "multi-surface" modelling approach has been developed to simultaneously predict the leaching and reactive transport of a broad range of major and trace elements (i.e., pH, $\mathrm{Na}, \mathrm{Al}, \mathrm{Fe}, \mathrm{Ca}, \mathrm{SO}_{4}, \mathrm{Mg}, \mathrm{Si}, \mathrm{PO}_{4}, \mathrm{CO}_{3}, \mathrm{Cl}, \mathrm{Ni}, \mathrm{Cu}, \mathrm{Zn}, \mathrm{Cd}, \mathrm{Pb}, \mathrm{Mo}$ ) and fulvic acids from MSWI bottom ash. The geochemical part of the model approach incorporates surface complexation/precipitation on Fe/Al (hydr)oxides, complexation with humic and fulvic acids (HA and FA, respectively) and mineral dissolution/precipitation. In addition, a novel approach is used to describe the dynamic leaching of FA, based on the surface complexation of FA on Fe/Al (hydr)oxides. To enable reactive transport calculations, the geochemical part of the model is combined with advective/dispersive transport of water and first-order mass transfer between mobile and stagnant zones. Using a single, independently determined set of input parameters, adequate model predictions are obtained for the leaching of a broad range of elements under widely different conditions, as verified with data from the European standardised pH-static and percolation leaching tests (TS 14997 and TS 14405, respectively). The percolation tests were operated at different flow velocities and with flow interruptions to enable verification of the local equilibrium assumption. Although the combination of experimental and modelling results indicates that the leaching of major solubility-controlled elements occurs largely under local equilibrium conditions, this study has led to the identification of physical non-equilibrium processes for non-reactive soluble salts, as well as possible sorption-related non-equilibrium processes for the leaching of Mo, FA and associated trace metals. Further improvement of the reactive transport model can be achieved by a more mechanistic description of the (dynamic) leaching behaviour of humic substances. As the modelling approach outlined in this study is based on the fundamental processes that underlie leaching, the approach is expected to be also applicable to other granular contaminated materials application scenarios and conditions. Therefore, the combination of standardized leaching test methods, selective chemical extractions and mechanistic modelling, constitutes a promising generic approach to assess the long-term environmental impact of the application of granular contaminated materials in the environment.
\end{abstract}

(C) 2008 Elsevier Ltd. All rights reserved.

\footnotetext{
* Corresponding author. Address: Energy Research Centre of the Netherlands (ECN), P.O. Box 1, 1755 ZG Petten, The Netherlands. Tel.: +3122456 4218; fax: +31224568163.

E-mail address: comans@ecn.nl (R.N.J. Comans).
} 


\section{Introduction}

Percolation tests are commonly used instruments to estimate the long-term percolation-dominated release potential from granular waste materials (e.g., NEN 7343 (NEN, 2003); TS 14405 (CEN/ TC292, 2004)). For a process-based interpretation of test results and their translation to field situations, sufficient understanding is required of the geochemical and mass transfer processes that control the leaching of contaminants in a percolation regime. Reactive transport modelling is a potentially valuable instrument to identify and describe the dynamic leaching processes of contaminants from waste materials (the "source term") as well as their further rate of transport in soil and groundwater, and may form a basis for the development of realistic regulatory limits.

Municipal solid waste incineration (MSWI) bottom ash is a particularly relevant material to study reactive transport processes, as it is the most significant residual waste stream from MSW incineration and is re-used in many countries as a construction product (Chandler et al., 1997). The material is known for its complex physicochemical characteristics and metastable mineralogical composition (Zevenbergen et al., 1994; Chandler et al., 1997) and is considerably enriched in potentially toxic trace elements compared to its parent material (Chandler et al., 1997). Although geochemical models have been used successfully to identify the leaching processes in MSWI bottom ash in batch experiments (e.g., Johnson et al., 1996; Meima and Comans, 1997, 1999; Dijkstra et al., 2006a), reports on the application of such models to dynamic MSWI bottom ash systems are, however, relatively scarce (Bäverman et al., 1997; Dijkstra et al., 2002; Baranger et al., 2002; Gardner et al., 2002; Mostbauer and Lechner, 2006).

Dijkstra et al. (2002) used a reactive transport model based on equilibrium chemistry to identify processes that control the leaching of major and trace elements from weathered MSWI bottom ash in a percolation test. In that study, local non-equilibrium processes were inferred from the relatively abrupt changes that the modelled leaching curves showed in comparison with the gradual concentration changes observed experimentally (Dijkstra et al., 2002). It was concluded that model predictions could be improved by including both nonequilibrium processes and a model for the reactive transport of dissolved organic C (DOC), because of the dominant role of organic ligands in the facilitated transport of metals.

Recent work indicates that the leaching of natural humic substances, in particular fulvic acids (FA) of which DOC in MSWI bottom ash leachates is partially composed, is the key process responsible for the facilitated leaching of $\mathrm{Cu}$ and possibly other metals (van Zomeren and Comans, 2004). In turn, the leaching of FA from MSWI bottom ash is most likely controlled by adsorption of FA to (neoformed) $\mathrm{Fe} / \mathrm{Al}$ (hydr)oxides present in the bottom ash matrix (Dijkstra et al., 2006b). Based on these insights, conditional surface complexation constants for FA adsorption to Fe/Al (hydr)oxides have been derived that adequately describe FA leaching in fresh MSWI bottom ash (Dijkstra et al., 2006b).

The role of kinetics in the leaching of major and trace elements from MSWI bottom ash has recently been investigated in detail in batch $\mathrm{pH}$-dependent leaching experiments (Dijkstra et al., 2006a). It was concluded that even at short equilibration times $(\sim 48 \mathrm{~h})$ most major and trace elements closely approach equilibrium model curves, in particular at the "natural" $\mathrm{pH}$ of the sample (Dijkstra et al., 2006a). Although this observation is promising for the application of equilibrium geochemical models to dynamic systems, the validity of the local equilibrium assumption in percolation tests such as TS 14405 (CEN/TC292, 2004) is yet to be demonstrated.

This paper presents a predictive, "multi-surface" geochemical modelling approach that is based on the above mentioned recent insights in the processes that control the speciation and leaching of elements in MSWI bottom ash. To achieve a more general applicability of the modelling approach with respect to other granular materials than MSWI bottom ash, the approach aims for consistency between the hypothesized processes, the chosen (sorption) models that simulate these processes, necessary model input parameters and experimental methods to determine these parameters. Since fundamental processes on a molecular scale have general validity, models that are based on these processes (referred to as "mechanistic" models) are, therefore, in this approach preferred over empirical-based models.

The approach is used to predict the simultaneous leaching of a wide range of major and trace elements (i.e., $\mathrm{pH}, \mathrm{Na}, \mathrm{Al}, \mathrm{Fe}, \mathrm{Ca}, \mathrm{SO}_{4}, \mathrm{Mg}, \mathrm{Si}, \mathrm{PO}_{4}, \mathrm{CO}_{3}, \mathrm{Cl}$, $\mathrm{Ni}, \mathrm{Cu}, \mathrm{Zn}, \mathrm{Cd}, \mathrm{Pb}, \mathrm{Mo}$ ) and FA from MSWI bottom ash under widely different batch and dynamic conditions. The geochemical part of the model includes mineral dissolution/precipitation as well 
as sorption processes to multiple reactive surfaces, i.e., surface complexation/precipitation on $\mathrm{Fe}-\mathrm{Al}$ (hydr)oxides, and complexation of ions with humic and fulvic acids. For this purpose, sorption models are selected with a preference for models for which "generic" parameter sets have been derived. Although such parameter sets may not provide the "best" description of measurements of a particular system, these parameter sets are internally consistent and therefore of a more general validity.

To enable reactive transport calculations, the geochemical part of the model is extended with one-dimensional, convective/dispersive transport of water combined with first-order mass transfer between mobile and stagnant zones ("dual porosity”, e.g., Toride et al., 1999, and references therein).

To parameterize the model, an independently determined set of input parameters is collected from selective chemical extractions (i.e., to determine the amounts and type of reactive surfaces) and low-pH extracts to obtain estimates of the amounts of elements available for leaching. The selected (sorption) models and associated parameters sets are applied without modification and only the published "generic" thermodynamic and binding parameters are used, i.e., without parameter fitting.

Using the same set of input parameters, the modelling approach is verified with data collected from two European-wide standardized leaching tests differing in concept and conditions, i.e., the batch pH-static test TS 14997 (CEN/TC292, 2006a) and the European standardized percolation test TS 14405 (CEN/TC292, 2004). The collected pH dependent leaching data are used to verify whether the geochemical processes that control the leaching are sufficiently described by the geochemical model. Data from the percolation tests, operated with different flow velocities and with flow interruptions, are used to evaluate the validity of the local equilibrium assumption and the robustness of the reactive transport model predictions.

Using the approach outlined above, this study aims to provide a detailed insight into the mechanisms that control the leaching of major and trace elements from MSWI bottom ash in batch and percolation regimes. In addition, this work aims to demonstrate the effectiveness of coupling the present generation of geochemical models with a transport model to predict complex and dynamic leaching scenarios, of which the percolation-dominated leaching of MSWI bottom ash is a representative and relevant case study. Finally, the possible implications that the process-level insights from this study have on the settings of standardized percolation tests such as TS 14405 are briefly discussed.

\section{Materials and methods}

\subsection{MSWI bottom ash samples}

A freshly quenched MSWI bottom ash sample was collected from a Dutch MSW Incinerator plant in early 2004. Prior to the leaching and extraction experiments, the sample was dried at $40{ }^{\circ} \mathrm{C}$ and sieved to pass a $<4 \mathrm{~mm}$ stainless steel sieve, yielding about $43 \%$ of the initial dry sample weight. Sieving was preferred over size-reduction to prevent breaking-up of (weathered) grains and the creation of fresh surfaces. This sample has previously been described by Dijkstra et al. (2006b) in which it is referred to as the "fresh" sample.

\subsection{Batch $p H$-static leaching experiments}

The batch pH-dependence leaching experiments conducted with this bottom ash sample have been described in detail elsewhere (Dijkstra et al., 2006b). In summary, the leaching experiments were carried out largely according to the European standard for the pH-static test TS 14997 (CEN/TC292, 2006a) on individual sub-samples that were each equilibrated for $48 \mathrm{~h}$, at a specific $\mathrm{pH}$ value between $\mathrm{pH} 2$ and 12 (including the native $\mathrm{pH}$ of the bottom ash samples that was not adjusted, $\sim \mathrm{pH} 11.2$ ) and at a liquid-to-solid $(\mathrm{L} / \mathrm{S})$ ratio of $10 \mathrm{~L} / \mathrm{kg}$.

\subsection{Percolation tests with different flow velocities and flow interruption}

The percolation tests were performed largely according to TS 14405 (CEN/TC292, 2004). The columns (borosilicate glass, inner diameter $5 \mathrm{~cm}$ ) were equipped with $10 \mu \mathrm{m}$ PTFE filters at the inlet and outlet of the columns. The dry bottom ash was added to the columns in layers of a few $\mathrm{cm}$ and packed by shaking and pushing gently with a rod until a filling height of $\pm 20 \mathrm{~cm}$ was reached. Nanopure water of neutral $\mathrm{pH}$ was used as the influent solution. The packed columns were water saturated and pre-equilibrated for $72 \mathrm{~h}$, as prescribed by TS 14405 , after which the influent was pumped in up-flow direction. Computer-controlled flow controllers were used assuring a constant flow velocity during the experiments. Fractions were collected 
automatically at cumulative liquid-to-solid ratio (L/ S) values of $0.2,0.5,1,2,5$ and $10(\mathrm{~L} / \mathrm{kg})$ and a number of intermediate fractions (see below). Effluent fractions were collected in acid-cleaned PE bottles. Tubing conducting the effluent, as well as the effluent collection bottles, was kept under a continuous flow of moistened $\mathrm{N}_{2}$ to prevent carbonation and oxidation of the leachates. Possible photosynthetic growth (e.g., algae) was prevented by wrapping the column and effluent collection bottles with Al foil. Shortly after collection of each effluent fraction, $\mathrm{pH}$, redox potential and conductivity were determined, and sub-samples for chemical analysis were taken and filtered through $0.45 \mu \mathrm{m}$ membrane filters. The clear filtrates were acidified with concentrated $\mathrm{HNO}_{3}$ (suprapure) and analyzed by ICP-AES to obtain solution concentrations of $\mathrm{Al}, \mathrm{As}, \mathrm{Ba}, \mathrm{Ca}$, $\mathrm{Cd}, \mathrm{Co}, \mathrm{Cr}, \mathrm{Cu}, \mathrm{Fe}, \mathrm{K}, \mathrm{Mg}, \mathrm{Mn}, \mathrm{Mo}, \mathrm{Na}, \mathrm{Ni}, \mathrm{P}, \mathrm{Pb}$, $\mathrm{S}, \mathrm{Sb}, \mathrm{Se}, \mathrm{Si}, \mathrm{Sn}, \mathrm{Sr}, \mathrm{V}$ and $\mathrm{Zn}$. A carbon analyzer (Shimadzu TOC 5000A) was used to determine dissolved inorganic and organic $\mathrm{C}$ in non-acidified fractions. Chloride and sulphate were determined by ion chromatography (IC). It was assumed that total $\mathrm{P}$ as measured by ICP-AES equated to $\mathrm{PO}_{4}$.

In deviation of TS 14405, the column tests were performed at different flow velocities and with flow interruptions during the course of the experiment in order to verify the local equilibrium assumption. The experiment referred to as "standard" was conducted with a flow velocity of $12 \mathrm{~mL} / \mathrm{h}$, which approximates the flow rate prescribed by TS 14405. The "fast" experiment was conducted with a 4 times higher flow rate of $48 \mathrm{~mL} / \mathrm{h}$. In both the "standard" and the "fast" experiment, the flow was stopped for $77 \mathrm{~h}$ at $\mathrm{L} / \mathrm{S} \sim 2$ and $70 \mathrm{~h}$ at $\mathrm{L} /$ $\mathrm{S} \sim 10 \mathrm{~L} / \mathrm{kg}$. After the flow interruption periods, the pump was started and an "equilibrated" leachate fraction of about $120 \mathrm{~mL}$ was collected, which is slightly less than 1 pore volume $(\sim 160 \mathrm{~mL})$. The relevant characteristics of the column experiments are summarized in Table 1.

\subsection{Geochemical and transport modelling}

The complete geochemical and transport model outlined in the paragraphs below is implemented in the ORCHESTRA modelling framework (Meeussen, 2003).

\subsubsection{Geochemical modelling approach}

Inorganic speciation and mineral solubility was calculated using thermodynamic data from MINT-
Table 1

Characteristics of the percolation tests

\begin{tabular}{|c|c|c|}
\hline & Standard & Fast \\
\hline Flow rate $(\mathrm{mL} / \mathrm{h})$ & 12 & 48 \\
\hline Dry weight of bottom ash ( $\mathrm{g}$ ) & 562 & 566 \\
\hline Filling height $(\mathrm{cm})$ & 20 & 21 \\
\hline Saturated pore volume $(\mathrm{mL})^{\mathrm{a}}$ & 165 & 178 \\
\hline Initial $\mathrm{L} / \mathrm{S}$ ratio $(\mathrm{L} / \mathrm{kg})^{\mathrm{b}}$ & 0.29 & 0.31 \\
\hline Residence time $(\mathrm{h})^{\mathrm{c}}$ & 13.8 & 3.7 \\
\hline Fraction \# & \multicolumn{2}{|c|}{ Cumulative $\mathrm{L} / \mathrm{S}(\mathrm{L} / \mathrm{kg})$} \\
\hline $1^{\mathrm{d}}$ & $0.23(72 \mathrm{~h})$ & $0.24(72 \mathrm{~h})$ \\
\hline 2 & 0.58 & 0.66 \\
\hline 3 & 1.15 & 1.31 \\
\hline 4 & 1.95 & 2.04 \\
\hline 5 & $2.16(77 \mathrm{~h})$ & $2.23(77 \mathrm{~h})$ \\
\hline 6 & 5.20 & 5.16 \\
\hline 7 & 9.88 & 9.57 \\
\hline 8 & $10.09(70 \mathrm{~h})$ & $9.96(70 \mathrm{~h})$ \\
\hline
\end{tabular}

The cumulative L/S values in bold indicate "equilibrated" fractions after flow interruption (between brackets the duration of flow interruption (h)). The "standard" column test is performed with the flow velocity prescribed by the European percolation test standard TS 14405 (CEN/TC292, 2004).

${ }^{\text {a }}$ Water volume in the saturated column, determined gravimetrically.

${ }^{b}$ Initial L/S ratio calculated from saturated pore volume and mass of dry bottom ash.

c Average residence time of the eluate calculated from the saturated pore volume and flow rate.

${ }^{d}$ Initial equilibration period prescribed by TS 14405 (CEN/ TC292, 2004).

EQA2 version 4.0 (US-EPA, 1999). Specific and non-specific sorption of protons and ions to humic and fulvic acids (HA and FA, respectively) was modelled with the NICA-Donnan model (Kinniburgh et al., 1999) using the set of "generic" binding parameters of Milne et al. (2003) except for the binding of Fe-III to FA, for which the more recent NICA-Donnan parameters derived by Hiemstra and Van Riemsdijk (2006) were used. It was assumed that $50 \%$ of HA and FA consists of C (De Wit, 1992).

The generalized two layer model (GTLM) of Dzombak and Morel (1990) was used to model surface complexation and surface precipitation of ions to hydrous ferric oxide (HFO). Amorphous Al (hydr)oxides present in the bottom ash matrix were considered as potentially important sorbent minerals. Following Meima and Comans (1998), HFO was taken as a surrogate sorbent for these surfaces in the model, as no complete and systematic database for sorption reactions on $\mathrm{Al}$ (hydr)oxides is currently available. For detail and justification of this approach the reader is referred to Meima and 
Comans (1998). HFO was also used as a surrogate sorbent mineral for crystalline Fe (hydr)oxide surfaces, however, site densities were calculated using a lower specific surface area of $100 \mathrm{~m}^{2} / \mathrm{g}$ (Hiemstra et al., 1989).

The surface complexation constants of Dzombak and Morel (1990) were included in the model for $\mathrm{H}$, $\mathrm{Ca}, \mathrm{Ba}, \mathrm{Mg}, \mathrm{Mn}, \mathrm{Ni}, \mathrm{Cu}, \mathrm{Zn}, \mathrm{Cd}, \mathrm{Pb}, \mathrm{Sb}, \mathrm{Mo}, \mathrm{Si}$, $\mathrm{SO}_{4}$ and $\mathrm{PO}_{4}$. The surface complexation constant of the low affinity site for $\mathrm{Pb}$ was considered an underestimate by Dzombak and Morel (1990), therefore a higher $\log K$ value of 1.7 was used to be consistent with the general trend of an approximate $3 \log$-unit difference between the sorption constants for the high and low affinity sites (Dzombak and Morel, 1990). The adsorption of carbonate was modelled using the surface complexation constants derived by Appelo et al. (2002). For surface precipitation of trace metals to Fe- and Al-(hydr)oxides, surface precipitate solubility constants were adopted from Farley et al. (1985) for $\mathrm{Pb}, \mathrm{Cd}$ and Zn.

Surface complexation of FA to Fe- and Al(hydr)oxides was modelled using the reactions and conditional surface complexation constants derived by Dijkstra et al. (2006b) for the same MSWI bottom ash sample. A molar weight of $1000 \mathrm{~g} \mathrm{FA} /$ mol is assumed (Filius et al., 2000). The leaching of HA was not taken into account in the forward model predictions, because the underlying processes of HA solid/solution partitioning are in general, and for MSWI bottom ash in particular, not sufficiently well known. Moreover, HA concentrations were only in a minority of the cases detectable in the leachates of the $\mathrm{pH}$ dependence test (Dijkstra et al., 2006b) and in the column effluent (Section 3.2.2). Consequences of this model setup will be discussed in Sections 3.2.3.5 and 4.1.

Component activities were calculated with the Davies equation as ionic strengths in the leachates were up to $\sim 0.5 \mathrm{M}$, at which Debye-Hückel is not applicable (Stumm and Morgan, 1981). A moderately oxidizing environment was assumed $(\mathrm{pH}+\mathrm{pe}=15)$, in agreement with measured redox potentials in batch experiments with similar MSWI bottom ash samples (Meima and Comans, 1997) and in the percolation tests (see Section 3.2).

\subsubsection{Parameterization of the geochemical model}

All geochemical model input parameters, expressed in the appropriate units, are presented in Table 2 and will be explained below. Independent
Table 2

Estimated available concentrations of elements and reactive surfaces that serve as input in the geochemical and transport model

\begin{tabular}{lll}
\hline Parameter & Value & Units \\
\hline $\mathrm{Si}^{\mathrm{a}}$ & $2.45 \mathrm{E}+00$ & $\mathrm{~mol} / \mathrm{kg}$ \\
$\mathrm{Ca}$ & $1.59 \mathrm{E}+00$ & $\mathrm{~mol} / \mathrm{kg}$ \\
$\mathrm{Al}^{\mathrm{a}}$ & $1.35 \mathrm{E}+00$ & $\mathrm{~mol} / \mathrm{kg}$ \\
$\mathrm{CO}_{3}$ & $7.00 \mathrm{E}-01$ & $\mathrm{~mol} / \mathrm{kg}$ \\
$\mathrm{Fe}$ & $2.93 \mathrm{E}-01$ & $\mathrm{~mol} / \mathrm{kg}$ \\
$\mathrm{Mg}$ & $1.83 \mathrm{E}-01$ & $\mathrm{~mol} / \mathrm{kg}$ \\
$\mathrm{Cl}$ & $1.47 \mathrm{E}-01$ & $\mathrm{~mol} / \mathrm{kg}$ \\
$\mathrm{Na}$ & $1.47 \mathrm{E}-01$ & $\mathrm{~mol} / \mathrm{kg}$ \\
$\mathrm{SO}$ & & $\mathrm{mol} / \mathrm{kg}$ \\
$\mathrm{Zn}$ & $1.39 \mathrm{E}-01$ & $\mathrm{~mol} / \mathrm{kg}$ \\
$\mathrm{Cu}$ & $5.37 \mathrm{E}-02$ & $\mathrm{~mol} / \mathrm{kg}$ \\
$\mathrm{Mn}$ & $1.07 \mathrm{E}-02$ & $\mathrm{~mol} / \mathrm{kg}$ \\
$\mathrm{Ni}$ & $7.18 \mathrm{E}-03$ & $\mathrm{~mol} / \mathrm{kg}$ \\
$\mathrm{Pb}$ & $1.94 \mathrm{E}-03$ & $\mathrm{~mol} / \mathrm{kg}$ \\
$\mathrm{Ba}$ & $1.31 \mathrm{E}-03$ & $\mathrm{~mol} / \mathrm{kg}$ \\
$\mathrm{Cd}$ & $8.14 \mathrm{E}-05$ & $\mathrm{~mol} / \mathrm{kg}$ \\
$\mathrm{PO}{ }^{b}$ & $3.71 \mathrm{E}-05$ & $\mathrm{~mol} / \mathrm{kg}$ \\
$\mathrm{Mo}$ & $1.00 \mathrm{E}-04$ & $\mathrm{~mol} / \mathrm{kg}$ \\
& $9.01 \mathrm{E}-06$ & \\
$\mathrm{Fulvic}$ acids & & $\mathrm{mol} / \mathrm{kg}$ \\
$\mathrm{Fe} / \mathrm{Al}$ (hydr)oxides & ${ }^{\mathrm{d}}$ & $\mathrm{kg} / \mathrm{kg}$ \\
$\mathrm{Specific} \mathrm{surface} \mathrm{area}$ & & $\mathrm{m}{ }^{2} / \mathrm{kg}$ \\
\hline
\end{tabular}

${ }^{\text {a }}$ Derived from reaction stoichiometry, see text.

b In the batch calculations fixed to $1 \mathrm{E}-5 \mathrm{~mol} / \mathrm{L}$, see text.

c A molar weight is used of $1000 \mathrm{~g} \mathrm{FA} / \mathrm{mol}$ (Filius et al., 2000).

d As measured by selective chemical extractions, see Dijkstra et al. (2006b).

e The overall specific surface area is calculated from the weighted contributions of amorphous Fe- and Al-(hydr)oxides for which $600 \mathrm{~m}^{2} / \mathrm{g}$ is used (Dzombak and Morel, 1990) and crystalline Fe-(hydr)oxides for which a specific surface area of $100 \mathrm{~m}^{2} / \mathrm{g}$ is used (Hiemstra et al., 1989).

estimates of the amount of reactive surfaces present in the bottom ash matrix, which are required for sorption modelling, were made by selective chemical extractions. Amounts of "reactive" Fe- and Al(hydr)oxides in the bottom ash sample, as estimated by selective chemical extraction, were adopted from Dijkstra et al. (2006b). In short, the amounts of amorphous and crystalline $\mathrm{Fe}$ (hydr)oxides in the bottom ash matrix were estimated by ascorbate and dithionite extractions, respectively, following the protocol of Kostka and Luther (1994). The amount of amorphous Al (hydr)oxides was estimated by an oxalate extraction according to Blakemore et al. (1987).

The solid and dissolved organic $\mathrm{C}$ in the sample and in the leachates were characterized quantitatively in terms of 3 fractions, i.e., HA, FA and hydrophilic acids (HY) by a batch procedure (van 
Zomeren and Comans, 2007) derived from the method currently recommended by the International Humic Substances Society (IHHS) (Thurman and Malcolm, 1981; Swift, 1996). Results of this method for the $\mathrm{pH}$ dependence test leachates of this bottom ash sample have been discussed in detail by Dijkstra et al. (2006b). Results for the leachates of the percolation tests will be presented in the results section.

Measurements at $\mathrm{pH} 2$ in the $\mathrm{pH}$-static test $(\mathrm{L} / \mathrm{S}$ 10) were used as first estimates of the concentrations of major and trace elements that are active in mineral dissolution/precipitation and sorption processes. It is assumed that cations are fully desorbed from Fe- and Al-(hydr)oxide surfaces (Meima and Comans, 1998) and that solubility controlling mineral phases are largely dissolved under these conditions. Concentrations measured at this $\mathrm{pH}$ value generally represent the maximum over the $\mathrm{pH}$ range investigated ( $\mathrm{pH} 2-12)$. Exceptions are the anionic species $\mathrm{MoO}_{4}^{2-}$ and FA for which concentrations measured at $\mathrm{pH} 12$ were used, assuming complete desorption from Fe- and Al-(hydr)oxides at this $\mathrm{pH}$ value (Dijkstra et al., 2006a,b). For carbonate, the total content in the sample was used as input in the model, as low or high $\mathrm{pH}$ extracts cannot be used for this purpose due to the degassing of $\mathrm{CO}_{2}(\mathrm{~g})$ and precipitation of carbonate minerals, respectively. The total content of carbonate was measured with a carbon analyzer (Shimadzu TOC 5000A). Consequences of the "availability" estimates for the different groups of elements will be further discussed in Sections 3.1 and 4.1 .

To predict MSWI bottom ash leaching as a function of $\mathrm{pH}$ the amounts listed in Table 2 were used as input in the model in combination with the liquid-solid value of $10 \mathrm{~L} / \mathrm{kg}$. The model calculates the speciation of all elements simultaneously at fixed $\mathrm{pH}$ values between $\mathrm{pH} 2$ and 12 (in steps of $0.1 \mathrm{pH}$ units). The selection of minerals that were allowed to precipitate during the calculation (Fig. 2) is discussed in the results section.

It is important to note that the present modelling approach differs in a number of aspects from the approach followed in the authors' previous studies (Meima and Comans, 1997; Dijkstra et al., 2006a). In short, the most important differences with previous work are:

(i) Solubility-controlled elements. In previous publications, model predictions for solubilitycontrolled elements are calculated according to the "infinite solids approach". In that approach, the leachate composition is calculated in equilibrium with an infinite amount of a selected mineral. Each element/mineral(s) combination requires a separate model run (for detail on this approach see Meima and Comans, 1997). In the present approach, the leachate composition is predicted using finite amounts of minerals that are constrained by the availability estimates listed in Table 2. The leachate composition based on the resulting mineral assemblage is calculated in a single model run.

(ii) Sorption-controlled elements. In previous publications, model predictions for sorption-controlled elements are calculated in the presence of total solution concentrations of major elements that compete for the same sorption sites. The total solution concentrations of these elements are fixed to their measured value to fully account for competition for available adsorption sites (for detail on this approach see Dijkstra et al., 2006a). In the present approach, the solution concentrations of all major and trace elements, whether they are based on solubility and/or sorption reactions, are predicted simultaneously in a single model run.

As the present model predictions are conducted for all solubility- and/or sorption-controlled elements simultaneously, the model predictions for one element depend on those of all other elements, as well on the parameters listed in Table 2.

\subsubsection{Transport model}

To predict MSWI bottom ash leaching in a percolation regime, the geochemical part of the model was extended with one-dimensional transport of water. To account for physical non-equilibrium (e.g., as indicated by observed "tailing" of element concentrations by Dijkstra et al., 2002; Gardner et al., 2002) the "dual porosity" approach (e.g., Toride et al., 1999) was followed. The dual porosity approach assumes that the liquid phase is partitioned in a mobile (flowing) and immobile (stagnant) zone. Solute exchange between the mobile and stagnant zone is approximated by a first-order process according to (e.g., Toride et al., 1999) and references therein):

$\theta_{\mathrm{im}} \mathrm{d} C_{\mathrm{im}} / \mathrm{d} t=\alpha\left(C_{\mathrm{m}}-C_{\mathrm{im}}\right)$ 
In Eq. (1), $\alpha$ is the first-order mass transfer coefficient $\left(\mathrm{s}^{-1}\right), C_{\mathrm{m}}$ is the concentration in the mobile zone, and $C_{\mathrm{im}}$ is the concentration in the stagnant zone. The parameters $\theta_{\mathrm{im}}$ and $\theta_{\mathrm{m}}$ are the stagnant and mobile portions of the total water filled porosity $\theta$, a fraction of the total volume (-):

$\theta=\theta_{\mathrm{m}}+\theta_{\text {im }}$

$\beta=\left(\theta_{\mathrm{m}} / \theta\right)$

The parameter $\beta$ in Eq. (3) is the ratio between the mobile and total porosity. The relatively simple dual porosity approach has the advantage over more complex diffusion models in that it can be used in situations where little is known about the physical characteristics of the stagnant zones.

The parameter $\theta$ was obtained gravimetrically from the saturated pore volume and total volume in the columns (Table 1). The two parameters $\alpha$ and $\beta$ of Eqs. (2) and (3) were fitted such that an adequate description was obtained for the leaching of $\mathrm{Cl}$ (see Section 3), of which conservative leaching behaviour is assumed. By implementing the fitted dual porosity parameters in the reactive transport model, it is implicitly assumed that the physical transport behaviour of all dissolved components is similar to that of $\mathrm{Cl}$. The fitted values for the parameter $\alpha$ and $\beta$ are presented and discussed in Section 3.2.3. The column was represented in the model by 10 cells ( 5 mobile and 5 stagnant cells). The numerical dispersivity generated by this schematization matches the observed dispersivity of $\mathrm{Cl}$ in the first eluate fractions. It is noted that ORCHESTRA enables a correct representation of flow interruption periods, i.e., by pausing the convective flow of water while diffusion processes continue.

TS 14405 prescribes relatively large effluent fractions, which vary in size from one to several pore volumes (e.g., see Table 1 and 1 pore volume $\sim 0.3 \mathrm{~L} / \mathrm{kg}$ ). To enable an appropriate comparison between transport model results and the collected data in the graphs (Figs. 3 and 4), the transport model output (fractions of equal size) was made compatible with the size of the different fractions in the test by averaging the modelled concentrations over the appropriate time intervals (i.e., L/S fractions).

The initial composition of the system was calculated from the "available" concentrations of elements expressed in $\mathrm{mol} / \mathrm{kg}$ solid material (Table 2) in combination with the initial liquid-solid ratio in the column $(\sim 0.3 \mathrm{~L} / \mathrm{kg}$, Table 1$)$. For protons, the initial $\mathrm{H}^{+}-\mathrm{OH}^{-}$mass balance was not measured but calculated from the initial $\mathrm{pH}$ of the system, which was estimated from the $\mathrm{pH}$ of the first fraction of the percolation test. After initialisation, column $\mathrm{pH}$ values were not fixed but calculated from the total $\mathrm{H}^{+}-\mathrm{OH}^{-}$mass balance per cell, which changes in time as a result of convective transport. It was assumed that the initial chemical composition of the system was equal for all mobile and stagnant cells in the column. The influent solution in the model was kept in equilibrium with the atmosphere $\left(p \mathrm{CO}_{2}=-3.5, \mathrm{pH}=5.67\right)$ and contained negligible concentrations of other elements.

\section{Results and discussion}

\section{1. pH-dependence leaching test data and model predictions}

Measured concentrations and model predictions of a number of important components, i.e., Al, $\mathrm{Ca}, \mathrm{SO}_{4}, \mathrm{Si}, \mathrm{Fe}$, fulvic acids (FA), $\mathrm{Ni}, \mathrm{Cu}, \mathrm{Zn}, \mathrm{Cd}$, $\mathrm{Pb}$ and $\mathrm{Mo}$ are shown in $\mathrm{pH}$-concentration diagrams in Fig. 1. For the selection of potentially solubility controlling processes in MSWI bottom ash for each of the elements of interest the reader is referred to previous work, in particular Dijkstra et al. (2006a) and references therein. For a detailed discussion on the solubility controlling processes of FA, FA-associated $\mathrm{Cu}$, and Mo see Dijkstra et al. (2006b).

The major components $\mathrm{Al}, \mathrm{Ca}, \mathrm{SO}_{4}$ and $\mathrm{Si}$ play a major role in governing leachate $\mathrm{pH}$ (Johnson et al., 1995; Meima and Comans, 1997) and, therefore, an adequate prediction of these components is crucial with respect to $\mathrm{pH}$-prediction by the transport model (see below). The minerals gibbsite (Al$\left.(\mathrm{OH})_{3}(\mathrm{~s})\right)$, gypsum $\left(\mathrm{CaSO}_{4} \cdot 2 \mathrm{H}_{2} \mathrm{O}(\mathrm{s})\right)$, calcite $\left(\mathrm{CaCO}_{3}(\mathrm{~s})\right)$, ettringite $\left(\mathrm{Ca}_{6} \mathrm{Al}_{2}\left(\mathrm{SO}_{4}\right)_{3}(\mathrm{OH})_{12} \cdot 26\right.$ $\left.\mathrm{H}_{2} \mathrm{O}(\mathrm{s})\right)$ and laumontite $\left(\mathrm{CaAl}_{2} \mathrm{Si}_{4} \mathrm{O}_{12} \cdot 4 \mathrm{H}_{2} \mathrm{O}(\mathrm{s})\right)$ were considered as plausible solubility controlling phases for these elements (Dijkstra et al., 2006a; and references therein) and were allowed to precipitate. For gibbsite the solubility product of Lindsay (1979) was used, as it generally provided a better description of Al solubility than the more soluble/ stable Al (hydr)oxides available in the MINTEQ 4.0 database (US-EPA, 1999). The laumontite solubility product was adopted from the MINTEQ 3.11 database (Allison et al., 1991). For calcite, a 10 times higher solubility product of $10^{-7.48}$ was used 

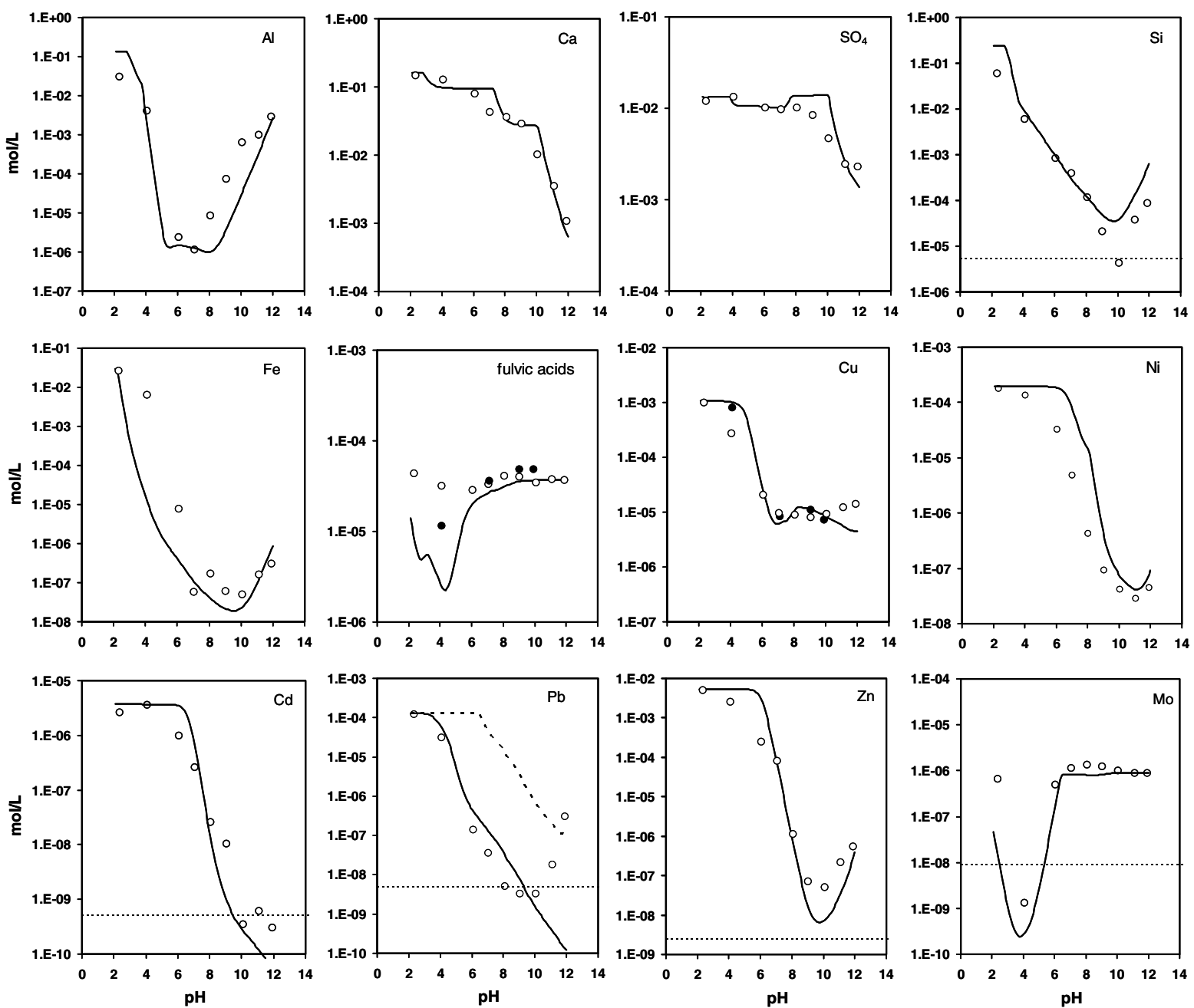

Fig. 1. Leached concentrations as a function of $\mathrm{pH}$ as measured with the $\mathrm{pH}$-static test (open circles) and model predictions (curves) for $\mathrm{Al}, \mathrm{Ca}, \mathrm{SO}_{4}, \mathrm{Si}, \mathrm{Fe}$, fulvic acids, $\mathrm{Cu}, \mathrm{Mo}, \mathrm{Ni}, \mathrm{Cd}, \mathrm{Pb}, \mathrm{Zn}$ and $\mathrm{Mo}$. The closed circles in the diagrams for fulvic acids and $\mathrm{Cu}$ are from independent experiments obtained after a longer equilibration time of $168 \mathrm{~h}$. Horizontal dashed lines represent detection limits. The dashed curve in the diagram for $\mathrm{Pb}$ represents a solubility curve of pure $\mathrm{Pb}(\mathrm{OH})_{2}(\mathrm{~s})$. See Section 3.1 for explanation.

according to the generally observed calcite oversaturation of about one order of magnitude in leachates from incineration residues and natural waters (see Meima and Comans, 1997; and references therein). The presence of this combination of minerals provides an excellent prediction of the leaching of $\mathrm{Al}, \mathrm{Ca}, \mathrm{SO}_{4}, \mathrm{Si}$, (Fig. 1), and also of carbonate that is not included in Fig. 1.

The initial estimates of the availability of $\mathrm{Al}$ and $\mathrm{Si}$ estimated at $\mathrm{pH} 2, \mathrm{~L} / \mathrm{S} 10$, led to inadequate model predictions. Therefore, the present estimate of the availability of $\mathrm{Al}$ and $\mathrm{Si}$ (as listed in Table 2) are calculated from the stoichiometry of laumontite $\left(\mathrm{CaAl}_{2} \mathrm{Si}_{4} \mathrm{O}_{12} \cdot 4 \mathrm{H}_{2} \mathrm{O}(\mathrm{s})\right)$, based on the measured availability of $\mathrm{Ca}$ (Table 2). In this calculation the
Ca-consumption by the simultaneous precipitation of calcite (limited by the $\mathrm{CO}_{3}$ availability) and ettringite (limited by the $\mathrm{SO}_{4}$ availability) is accounted for. The calculated amount of $\mathrm{Al}$ was insufficient to explain the observed saturation of gibbsite, and therefore a slight excess of $\mathrm{Al}$ was added such that gibbsite precipitates over the entire

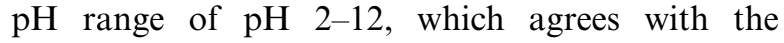
observed concordance of measured $\mathrm{Al}$ concentrations with Al-(hydr)oxide dissolution behaviour (Fig. 1). It is important to note that the derived Al- and $\mathrm{Si}$ availabilities are still well below their total content as measured by total digestion in the sample $(75 \%$ and $35 \%$ of their total content, respectively). Apparently, the availabilities of $\mathrm{Si}$ and $\mathrm{Al}$ 
are underestimated using $\mathrm{pH} 2$ extracts, and/or the solubility controlling mechanisms of the $\mathrm{Ca} / \mathrm{Al} / \mathrm{Si}$ in MSWI bottom ash at high $\mathrm{pH}$ are still insufficiently understood.

The availability estimate of $\mathrm{Ca}$ and $\mathrm{SO}_{4}$ (Table 2) could in principle be biased by the precipitation of gypsum at low pH (see Fig. 1). However, their availability estimated from an additional $\mathrm{pH}$-static experiment conducted at L/S 100 remained virtually unchanged, indicating that gypsum is already close to depletion at L/S 10 .

The solubility product for amorphous $\mathrm{Fe}$ hydroxide of Lindsay (1979) allows an adequate prediction of the measured Fe-solubility (Fig. 1), that is better than those obtained with either the more soluble or more stable $\mathrm{Fe}$ (hydr)oxides in the MINTEQ 4.0 database. The calculated solubility curves of $\mathrm{Al}$ and $\mathrm{Fe}$ are considerably influenced by complexation to FA, which follows from the relatively strong affinity of these cations for complexation with dissolved humic substances (Milne et al., 2003; Hiemstra and Van Riemsdijk, 2006). Adequate model predictions are also obtained for $\mathrm{Mg}$ (based on brucite solubility) and $\mathrm{Mn}$ (based on manganite solubility), of which their $\mathrm{pH}$-concentrations plots are not included in Fig. 1.

Modelled FA concentrations are sensitive to competitive adsorption of other anionic species in the low $\mathrm{pH}$ range, in particular to phosphate (Dijkstra et al., 2006b). In the present study, adequate model predictions of phosphate could not be obtained, and therefore the solution concentrations of phosphate were fixed to $10^{-5} \mathrm{M}$, which agrees with the fairly constant phosphate concentrations measured at $\mathrm{pH}>4$ (data and model not shown in Fig. 1). The resulting model descriptions for FA are adequate (Fig. 1). Clearly, phosphate leaching behaviour, due to its competitive influence on FA and other anionic species, is a source of uncertainty that requires further study.

The leaching of $\mathrm{Cu}$ is well predicted by surface complexation to $\mathrm{Fe}$ - and $\mathrm{Al}$-(hydr)oxides, and by allowing $\mathrm{Cu}(\mathrm{OH})_{2}$ (s) to precipitate as it becomes oversaturated, which occurs at $\mathrm{pH}>8$. At $\mathrm{pH}>6$, the leaching of $\mathrm{Cu}$ is primarily controlled by the availability and leachability of FA present in the MSWI bottom ash leachates due to the formation of strong $\mathrm{Cu}-\mathrm{FA}$ complexes (Dijkstra et al., 2006b). These interactions are well predicted by the model (Fig. 1). The anionic species $\mathrm{MoO}_{4}^{2-}$ is adequately predicted by (weak) surface complexa- tion at high $\mathrm{pH}$, and the formation of wulfenite $\left(\mathrm{PbMoO}_{4}(\mathrm{~s})\right)$ at low $\mathrm{pH}(1)$.

Leached Ni concentrations were modelled based on surface complexation to $\mathrm{Fe}$ - and Al-(hydr)oxides, and by allowing $\mathrm{Ni}(\mathrm{OH})_{2}$ (s) to precipitate as it becomes oversaturated (Dijkstra et al., 2006a). The solubility product of $\mathrm{Ni}(\mathrm{OH})_{2}(\mathrm{~s})$ was taken from the previous MINTEQ3.11 database (Allison et al., 1991), as the present solubility product of this phase (MINTEQ 4.0) led to overestimates by about one order of magnitude. The trend of leached $\mathrm{Ni}$ concentrations is well described by the model, in particular around the natural $\mathrm{pH}(\sim \mathrm{pH}$ 11.2). Although predicted $\mathrm{Ni}$ concentrations generally overestimate the measurements, it has been shown that $\mathrm{Ni}$ concentrations at $\mathrm{pH}<10$ continue to increase beyond equilibration times of $48 \mathrm{~h}$, suggesting slow desorption/dissolution processes (Dijkstra et al., 2006a).

Following the work of Meima and Comans (1998) and Dijkstra et al. (2006a), the leaching of $\mathrm{Zn}$ was modelled by surface precipitation to $\mathrm{Fe}$ and Al-(hydr)oxides, leading to adequate model predictions (Fig. 1). Measured concentrations of $\mathrm{Cd}$ and $\mathrm{Pb}$ (Fig. 1) are substantially lower than in these previous studies, which is the result of improved measurement techniques (Dijkstra et al., 2006a use leaching data from 1998). In the previous studies, the leaching of these elements was explained by surface complexation to Fe- and Al-(hydr)oxides (Meima and Comans, 1998; Dijkstra et al., 2006a), but preliminary model calculations showed that the present low concentrations cannot be explained solely by this process, at least not using the estimates for available concentrations and reactive surface area of Table 2 (not shown). Therefore, surface precipitation to $\mathrm{Fe}$ - and Al-(hydr)oxides was considered for these metals in the model, which led to adequate descriptions for $\mathrm{Cd}$ over the complete $\mathrm{pH}$ range, and for $\mathrm{Pb}$ up to $\mathrm{pH} 10$ (Fig. 1). Although neoformed calcite has been suggested to be an important scavenger of trace metals (Piantone et al., 2004), Meima and Comans (1998) tried to model the leaching of $\mathrm{Cd}$ from aged MSWI bottom ash by surface complexation and surface precipitation to calcite and strongly overestimated measured concentrations. Also attempts to model the leaching of $\mathrm{Pb}$ based on this process were unsuccessful (unpublished results). Therefore, based on the present model calculations, surface precipitation of $\mathrm{Cd}$ to iron- and aluminium (hydr)oxides seems more likely (Fig. 1). The concentrations of $\mathrm{Pb}$ around 
the natural $\mathrm{pH}(\sim 11.2)$ correspond better to those predicted by the solubility of pure $\mathrm{Pb}(\mathrm{OH})_{2}(\mathrm{~s})$ than by the surface precipitation model, as indicated by the dashed curve in Fig. 1. Further research, e.g., by using spectroscopic techniques, is needed to investigate the possible formation of surface precipitates/solid solutions of these metals in MSWI bottom ash. For the present reactive transport model (Section 3.2.3), the selection of solubility controlling processes for the metals $\mathrm{Cu}, \mathrm{Pb}, \mathrm{Ni}, \mathrm{Cd}$ and $\mathrm{Zn}$ will be based on the model scenario providing the closest agreement with the data around the natural $\mathrm{pH}$ of 11.2 in Fig. 1, anticipated on similar $\mathrm{pH}$ values of the percolation test leachates. Therefore, the leaching of $\mathrm{Cu}, \mathrm{Ni}$ and $\mathrm{Pb}$ around the natural $\mathrm{pH}$ is assumed to be controlled by the solubility of their respective (hydr)oxides, while for $\mathrm{Cd}$ and $\mathrm{Zn}$, surface precipitation to $\mathrm{Fe}$ - and $\mathrm{Al}-(\mathrm{hydr})$ oxides is assumed to be the controlling process.

Fig. 2 (left diagram) provides an overview of the minerals and surface precipitates that are allowed to form during the model run. The right diagram in Fig. 2 shows the measured and predicted acid neutralizing capacity (ANC). An adequate prediction of the $\mathrm{pH}$ using a reactive transport model depends on how accurately the acid/base buffering behaviour is described. The shape of the modelled ANC curve is related to the estimated availabilities of cations and anions (Table 2), the mineral phases that are allowed to precipitate (e.g., see the concordance resulting from calcite dissolution in both diagrams of Fig. 2) and the amount and type of reactive sur- faces in the model. The predicted ANC curve shows strong similarity to the measured ANC behaviour, although the latter is increasingly overestimated towards low $\mathrm{pH}$. It is noted, however, that substantial kinetic effects have been observed for the acid/ base consumption of MSWI bottom ash in particular at low pH (Dijkstra et al., 2006a).

\subsection{Percolation tests data and modelling results}

\subsubsection{Measured responses to flow velocity and flow interruptions}

Results of the percolation tests are presented in Figs. 3 and 4. The measured $\mathrm{pH}$ and conductivity, and leached concentrations of an assumed conservative element, $\mathrm{Cl}$, are presented as a function of the cumulative liquid-to-solid (L/S) ratio in Fig. 3. Leached concentrations of $\mathrm{Al}, \mathrm{Ca}, \mathrm{SO}_{4}, \mathrm{Si}, \mathrm{Fe}$, fulvic acids (FA), Ni, $\mathrm{Cu}, \mathrm{Zn}, \mathrm{Cd}, \mathrm{Pb}$ and $\mathrm{Mo}$ are shown in Fig. 4. The charge balance of the leachates was calculated from the chemical analysis results and amounts to $4.2 \pm 3 \%$, which is accurate given the complex leachate composition and high salt levels.

The initial $\mathrm{pH}$ of the leachates $(\mathrm{pH} \sim 10.8)$ increases after a few pore volumes $(\mathrm{L} / \mathrm{S} 0.6, \sim 2$ pore volumes) to fairly constant values of around $\mathrm{pH}=11.2$, which is equal to the "natural" $\mathrm{pH}$ measured in the $\mathrm{pH}$-static experiment without acid/base dosage. These $\mathrm{pH}$ values are in the range typically found for freshly quenched MSWI bottom ash (Meima and Comans, 1997). No systematic difference is observed between the $\mathrm{pH}$ measured in the
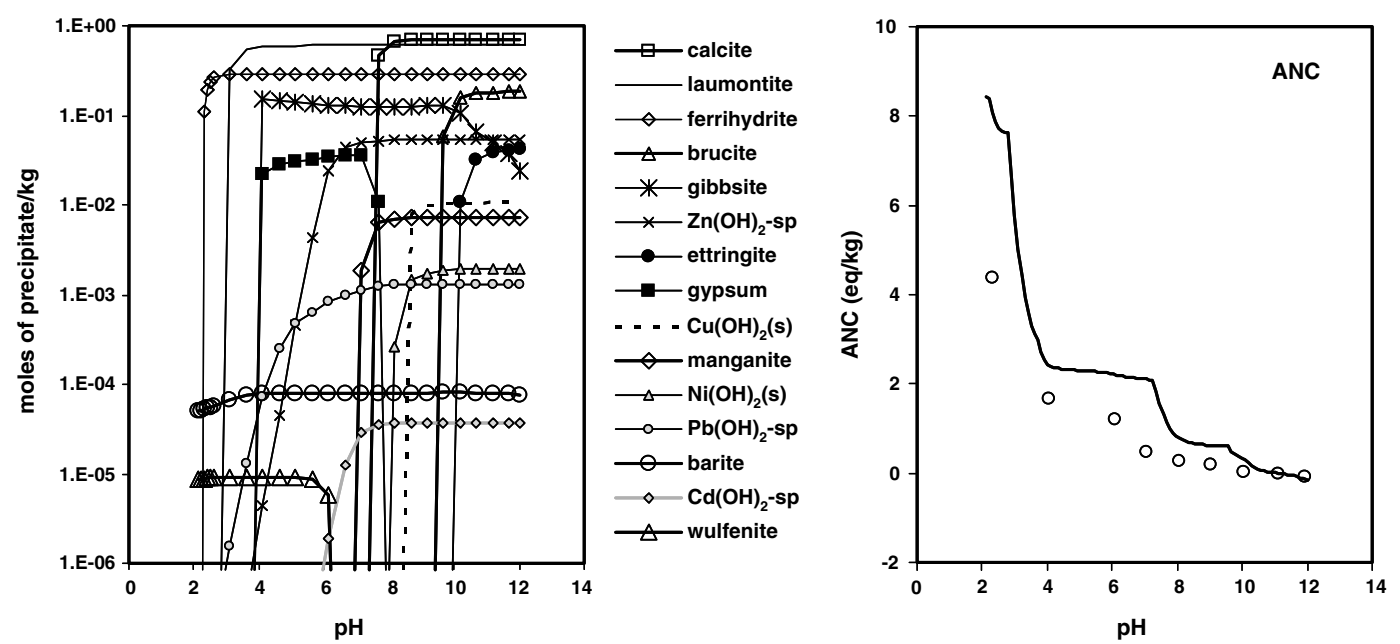

Fig. 2. Overview of the mineral phases and surface precipitates (denoted by -sp) that are allowed to precipitate as a function of $\mathrm{pH}$ during the model run (left diagram), and the measured versus predicted acid neutralizing behaviour of the material (right diagram). See Section 3.1 for explanation. 

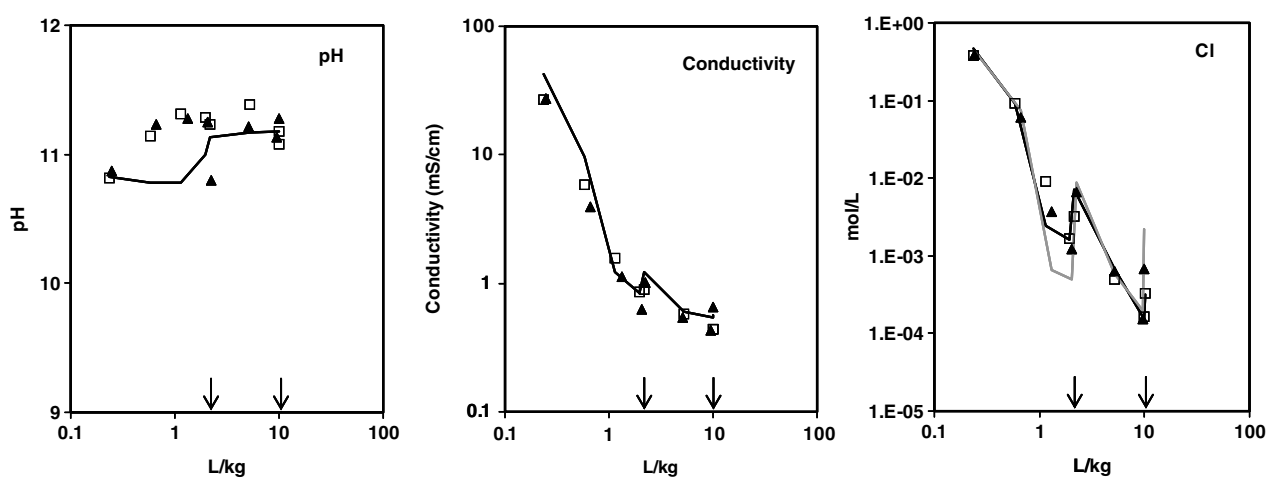

Fig. 3. Results of the percolation tests and model predictions for $\mathrm{pH}$, conductivity and the leaching of $\mathrm{Cl}$ expressed as a function of cumulative liquid-to-solid ratio $(\mathrm{L} / \mathrm{kg})$. Open squares are the data collected at the "standard" flow velocity (as prescribed by the percolation test TS 14405), closed triangles are the data collected at a 4 times higher flow velocity ("fast"). The arrows on the $x$-axis indicate the position of the equilibrated fractions that are collected immediately after flow interruption (at $\sim \mathrm{L} / \mathrm{S} 2.2$ and $\mathrm{L} / \mathrm{S} 10$, respectively). The solid lines in the diagrams for $\mathrm{pH}$ and conductivity represent model predictions. The solid black and grey curves in the diagram for $\mathrm{Cl}^{-}$are model descriptions based on the dual porosity approach for the "standard" and "fast" experiment, respectively, calculated by the same parameters (see Section 3.2.3).

standard and fast column, and virtually no response of $\mathrm{pH}$ on the flow interruptions is recorded. The lower $\mathrm{pH}$ value upon flow interruption at $\mathrm{L} / \mathrm{S} 2$ in the fast column is probably a measurement error, as a response of strongly $\mathrm{pH}$-dependent elements such as $\mathrm{Al}$ is absent (Fig. 4).

Measurements of the redox potential resulted in a somewhat constant relationship of $\mathrm{pH}+\mathrm{pe}=$ $16 \pm 0.5$, without observed sensitivity to flow velocity, and with marginal increased values after the flow interruptions (not shown). These values point to a moderately oxidising environment in the leachates (e.g., Brookins, 1988).

Values for the electrical conductivity (EC) strongly decrease during the first pore volumes as a result of the wash-out of soluble salts. Chloride concentrations decrease by almost 3 orders of magnitude over the course of the experiment and show a long "tailing" of element concentrations (Fig. 3). A considerable increase in $\mathrm{Cl}$ concentrations is measured in the eluate fractions directly following flow interruption (Fig. 3). This effect is clearly more pronounced in the fast column (a factor of 5 versus a factor of 2 increase, respectively, for the fast and standard flow velocity). The response on flow interruptions of assumed conservative elements is a typical indication for physical non-equilibrium processes (Brusseau et al., 1989; Koch and Fluhler, 1993), i.e., diffusional mass transfer between mobile and stagnant zones in the column. Such stagnant zones may consist of small pores in particles and/ or, on a larger scale, domains in the columns that do not actively take part in the transport process as a result of preferential flow paths. Similar responses to flow velocity and flow interruption were observed for $\mathrm{Na}$ and $\mathrm{Br}$ (not shown).

Overall, response on flow velocity was remarkably small for the leaching of a broad range of elements (Figs. 3 and 4). Expressed in cumulatively leached amounts (in $\mathrm{mol} / \mathrm{kg}$ ) after $\mathrm{L} / \mathrm{S} 10$, and averaged over all measured components by chemical analysis (35 components) and excluding measurements around detection limit, an $8 \pm 14 \%$ higher cumulative leaching is measured in the standard column relative to the fast column. Although responses upon flow interruption on individual column fractions are considerably large (see $\mathrm{Cl}$ ), the contribution of flow interruptions at L/S 2 and L/S 10 to the overall cumulatively leached amounts after L/S 10 is very small: $3 \pm 1 \%$ in the standard column, and a slightly higher $5 \pm 2 \%$ in the fast column.

\subsubsection{Leaching and composition of DOC in the percolation test leachates}

The leached DOC concentrations from both percolation tests were characterized in terms of HA, FA and HY (see Section 2.4.2). The results are presented in Fig. 5 and show that about $50 \%$ of the leached DOC consists of FA, a percentage that remains fairly constant during the course of the test. Low concentrations of HA are only measured in the first fractions of the percolation tests (Fig. 5). The above observations are similar for both flow velocities. In the fast column, the relative proportion of FA in the equilibrated fractions (i.e., after flow interruption at L/S 2.2 and L/S 10) are lower 

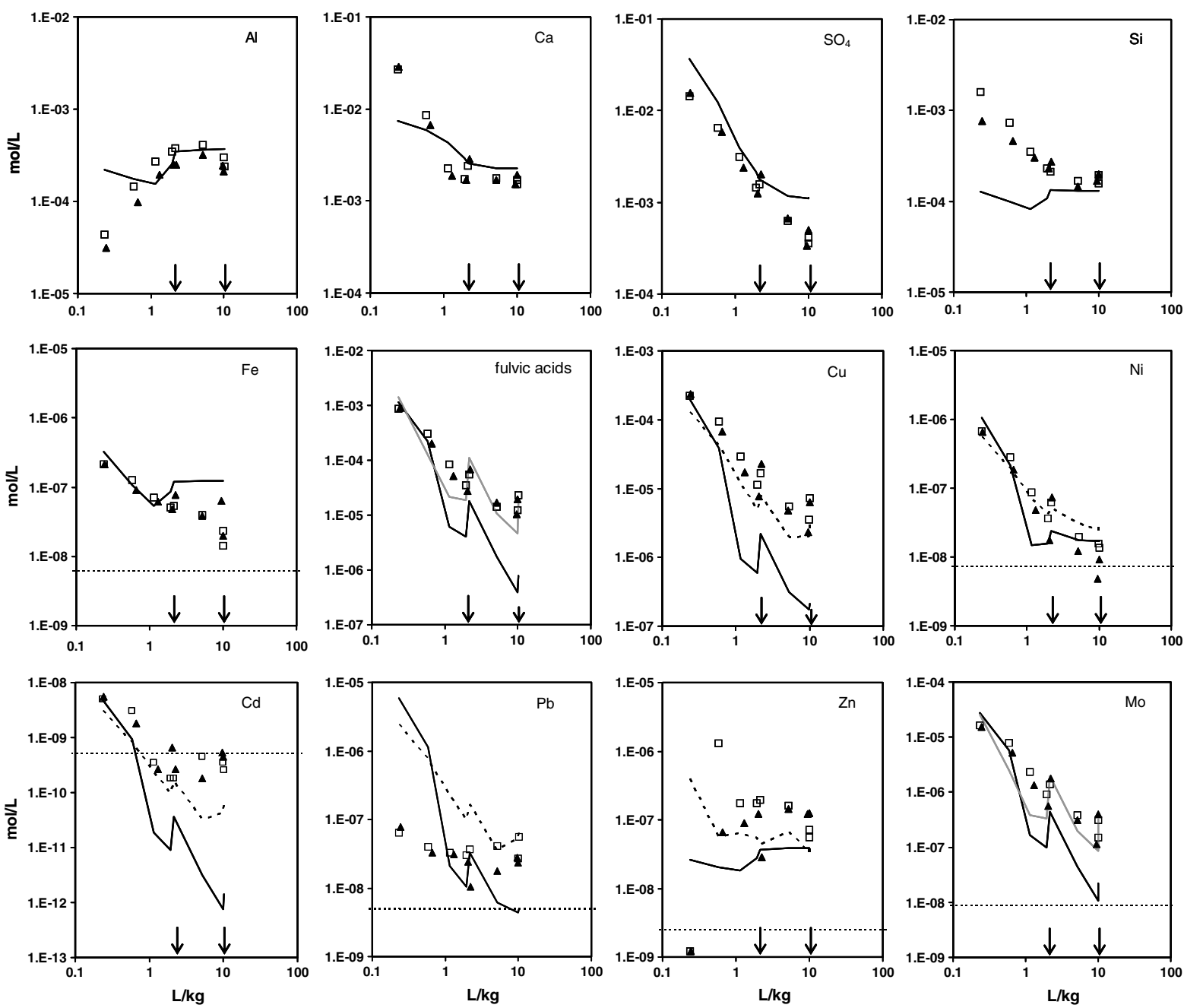

Fig. 4. Results of the percolation tests and model predictions for $\mathrm{Al}, \mathrm{Ca}, \mathrm{SO}_{4}, \mathrm{Si}, \mathrm{Fe}$, fulvic acids, $\mathrm{Cu}, \mathrm{Mo}, \mathrm{Ni}, \mathrm{Cd}, \mathrm{Pb}, \mathrm{Zn}$ and $\mathrm{Mo}$ expressed as a function of cumulative liquid-to-solid ratio $(\mathrm{L} / \mathrm{kg})$. Open squares are the data collected at the "standard" flow velocity (as prescribed by the percolation test TS 14405), closed triangles are the data collected at a 4 times higher flow velocity ("fast"). The arrows on the $x$-axis indicate the fractions collected immediately after flow interruption (at $\sim \mathrm{L} / \mathrm{S} 2.2$ and L/S 10, respectively). The solid lines represent model predictions by the reactive transport model. The dashed lines in the diagrams for $\mathrm{Cu}, \mathrm{Ni}, \mathrm{Cd}, \mathrm{Pb}$ and $\mathrm{Zn}$ are model predictions calculated for each data point separately (see Section 3.2.3 "metals"). Solid grey curves in the diagrams for FA and Mo represent an alternative model scenario in which a different set of kinetic parameters was used (for explanation see Section 3.2.3 "fulvic acids and molybdenum").

compared to the preceding and subsequent fractions (Fig. 5), while total DOC in these fractions have increased by a factor of $2-3$, indicating that the release of $\mathrm{HY}$ during the flow interruptions is faster than the release of FA. The effect of flow interruptions on the composition of DOC is less pronounced for the standard column (Fig. 5). The cumulatively leached amount of FA corresponds to $\sim 0.5 \mathrm{~g} \mathrm{FA} / \mathrm{kg}$ bottom ash, which is close to the measured availability in the $\mathrm{pH}$-static experiment of $\sim 0.37 \mathrm{~g} \mathrm{FA} / \mathrm{kg}$ (equivalent to $3.7 \mathrm{E}-4 \mathrm{~mol} \mathrm{FA} / \mathrm{kg}$ in Table 2 ) as well as to the estimated total FA content in the sample
(0.4 g FA/kg, Dijkstra et al., 2006b). These observations indicate that virtually all FA present in the MSWI bottom ash sample is washed out after L/ $\mathrm{S}=10$, which is in agreement with the observed weak interaction of FA with reactive surfaces present in the bottom ash matrix at high $\mathrm{pH}$ (Dijkstra et al., 2006b). The low leachability of HA from bottom ash can be attributed to the presence of relatively high amounts of di- and trivalent ions (e.g., $\mathrm{Ca}, \mathrm{Al}$ and $\mathrm{Fe}$ ), which reduce the solubility of HA by charge neutralisation and subsequent coagulation (Temminghoff et al., 1998; Weng et al., 2002). 

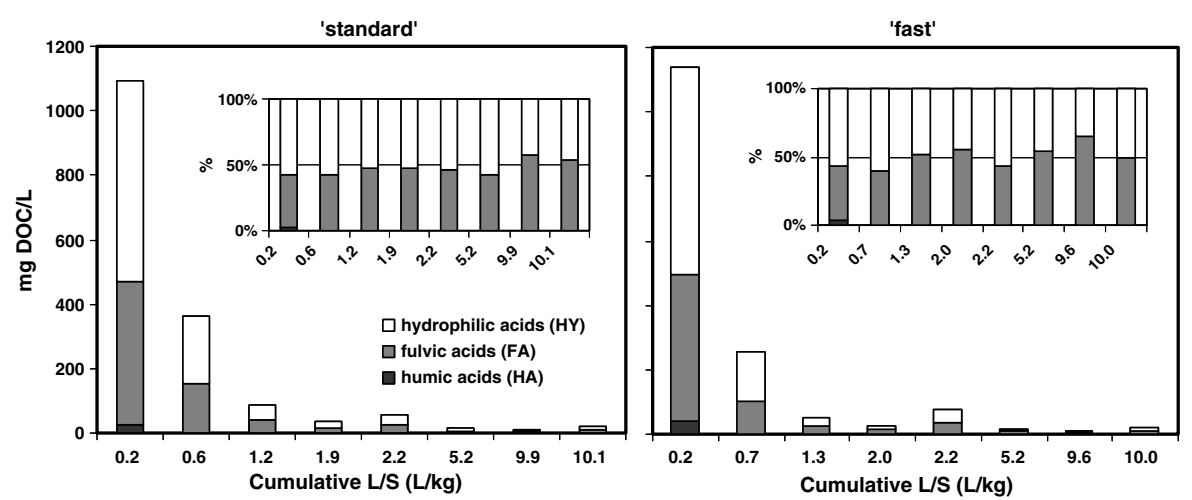

Fig. 5. Results of the characterization of organic C present in the MSWI bottom ash leachates from the percolation test in terms of hydrophilic acids, fulvic acids and humic acids, expressed in $\mathrm{mg}$ DOC/L as a function of cumulative liquid-to-solid ratio, L/S.

\subsubsection{Model predictions for the percolation test}

Model curves generated by the reactive transport model are included in Figs. 3 and 4 (for clarity only shown for the standard flow velocity; model predictions for the "fast" column were quite similar).

\subsubsection{Chloride. An excellent fitted transport} behaviour for $\mathrm{Cl}$ leaching was obtained with the dual porosity parameters $\alpha=5 \mathrm{E}-8 \mathrm{~s}^{-1}$ and $\beta=0.95$ (Fig. 3). Note also that the more pronounced effects of flow interruptions in the column operated at the higher flow velocity are adequately predicted when the same parameter values are used (Fig. 3).

It is possible to relate the exchange factor $\alpha$ to an effective diffusion coefficient using the size and geometry of the stagnant zone, according to the relationship of Van Genuchten (1985) cited in Appelo and Postma (2005). Such a physical interpretation of the values for $\alpha$ and $\beta$ is complicated as characteristics of the stagnant zones are unknown for this sample and for MSWI bottom ash in general. However, if it is assumed that the stagnant zones consist of micropores within spheres with a radius of $2 \mathrm{~mm}$ (i.e., the largest particle size fraction in the sample), an effective diffusion coefficient $\left(D_{\mathrm{e}}\right)$ in the order of $10^{-12}-10^{-13} \mathrm{~m}^{2} / \mathrm{s}$ is found (for details of this calculation see Appelo and Postma, 2005). This value is similar to that found by Gardner et al. (2002) for the leaching of conservative elements $(\mathrm{Na}$ and $\mathrm{Cl})$ from MSWI fly ash columns.

\subsubsection{2. $\mathrm{pH}$ and conductivity. The calculated $\mathrm{pH}$ of} the column leachate is determined by the estimated initial $\mathrm{pH}$ of the material ( $\sim \mathrm{pH} 10.8$, see Section 2$)$ in combination with the assumed set of minerals and, to a lesser extent, the amount and type of adsorbing surfaces. The same mineral assemblage present at the natural $\mathrm{pH}$ in the $\mathrm{pH}$-static experiments is predicted to precipitate in the columns (refer to the minerals present at $\mathrm{pH} \sim 11.2$ in Fig. 2), and complete depletion of these minerals from the column is not predicted up to $\mathrm{L} / \mathrm{S}=10$. The $\mathrm{pH}$ of the leachates is predicted well, although the time at which the $\mathrm{pH}$ increases from 10.8 to $\mathrm{pH} 11.2$ is somewhat overestimated (Fig. 3). The calculated eventual $\mathrm{pH}$ of $\sim 11.2$ is consistent with the equilibrium $\mathrm{pH}$ of the assumed mineral assemblage. Although the $\mathrm{pH}$ remains quite constant over the duration of the experiment, an adequate prediction of $\mathrm{pH}$ in systems with a more variable $\mathrm{pH}$ (i.e., in which a large portion of the available buffering capacity is consumed) strongly depends on an accurate prediction of the ANC (Fig. 2).

Electrical conductivity (EC) is a bulk parameter that is primarily determined by the major ions present in the leachates. EC was derived from the predicted ionic strength $(I)$ using the relationship $I(\mathrm{M})=0.013 \times \mathrm{EC}(\mathrm{mS} / \mathrm{cm})$ (Lindsay, 1979), which resulted in an excellent prediction of EC as a function of L/S (Fig. 3), indicating that the processes underlying the leaching of major ions are adequately captured by the model.

\subsubsection{Major elements. Leached concentrations of} the major components $\mathrm{Al}, \mathrm{Ca}, \mathrm{SO}_{4}$, are generally predicted adequately to excellently (Fig. 4). Adequate predictions were also obtained for other major elements not shown in Fig. 4, such as $\mathrm{Mg}$, $\mathrm{Mn}$ and $\mathrm{CO}_{3}$. Model predictions for $\mathrm{Si}$ and $\mathrm{Fe}$ are accurate within approximately one order of magnitude. Deviations between model predictions and 
data for major elements are particularly observed below $\mathrm{L} / \mathrm{S}=1$. These deviations are partly explained by an insufficiently accurate description of the $\mathrm{pH}$ during the first pore volumes (e.g., see the concordance in the model predictions for $\mathrm{pH}$ in Fig. 3 and $\mathrm{Al}$ in Fig. 4). Deviations may also arise from inaccurate estimates of the available concentrations in Table 2, to which the reactive transport predictions are very sensitive, and/or a still insufficient representation of processes in the model (see $\mathrm{Fe}$ and $\mathrm{Si}$ ).

\subsubsection{Fulvic acids and molybdenum. The reactive} transport model predicts a virtually conservative wash-out of FA from the column (Fig. 4), which follows from the predicted complete desorption at $\mathrm{pH}$ values around the natural $\mathrm{pH}$ of the sample $(\sim \mathrm{pH}$ 11.2; see Fig. 1). However, FA concentrations are increasingly underestimated by the model towards higher L/S ratios (Fig. 4). Fig. 4 shows that FA concentrations are described more accurately when using the cumulatively leached amount of FA as input in the model (i.e., $5 \mathrm{E}-4 \mathrm{~mol} / \mathrm{kg}$ ) instead of the estimated availability $(3.67 \mathrm{E}-4 \mathrm{~mol} / \mathrm{kg}$, Table $2)$, in combination with dual porosity parameters that are different from those for $\mathrm{Cl}\left(\alpha=2.5 \mathrm{E}-7 \mathrm{~s}^{-1}\right.$ and $\beta=0.75$ ). These modified dual porosity parameters for FA represent a higher release rate and a larger effective stagnant fraction relative to $\mathrm{Cl}$ $\left(\alpha=5 \mathrm{E}-8 \mathrm{~s}^{-1}\right.$ and $\left.\beta=0.95\right)$. Possible explanations for these deviating transport parameters of FA include sorption-related non-equilibrium (e.g., Brusseau et al., 1989) and/or a different physical transport behaviour as a result of an inhomogeneous distribution of the different components within and between the bottom ash particles.

There is a striking similarity between the leaching behaviour of FA and that of other anionic compounds, i.e., phosphate (not shown) and Mo (Fig. 4). These components show a similar "washout" pattern as FA. The components FA and Mo have in common that pronounced leaching kinetics have been observed in batch $\mathrm{pH}$-static leaching experiments at alkaline $\mathrm{pH}$ (Dijkstra et al., 2006a,b; see also FA behaviour in Fig. 1), while the model predictions indicate virtually $100 \%$ desorption in this $\mathrm{pH}$ region (Fig. 1). The grey solid curve in the diagram for Mo in Fig. 4 indicates that the transport behaviour of this component is adequately described using the same kinetic (i.e., "dual porosity") parameters as derived for FA. These similarities suggest a similar release process for FA and
Mo. Further research is required to establish whether the kinetic features observed for these compounds have a chemical (i.e., slow desorption kinetics) or physical nature.

3.2.3.5. Metals. The reactive transport model prediction for $\mathrm{Ni}$ is excellent over the full $\mathrm{L} / \mathrm{S}$ range, whereas for model predictions of $\mathrm{Cu}$ and $\mathrm{Cd}$, both show that initial leached concentrations are predicted adequately, but concentrations become increasingly underestimated toward higher $\mathrm{L} / \mathrm{S}$ ratios. Model predictions for $\mathrm{Pb}$ strongly overestimate the measurements at low L/S and are slightly better at higher $\mathrm{L} / \mathrm{S}$ where the deviation is approximately one order of magnitude. Rather exceptional behaviour is observed for $\mathrm{Zn}$, of which the concentration in the first fraction was found to be below detection limit. The reasons for this apparently anomalous behaviour are currently unknown. Concentrations towards higher L/S are predicted generally within a factor of $5-10$.

In order to identify the main cause of the trend that metal concentrations are increasingly underestimated towards higher L/S, additional model calculations were performed for each data point separately, using the measured $\mathrm{pH}$ and concentrations of HA, FA as input in the model (i.e., without transport of water as if they were batch experiments). The plausible assumption underlying these batch calculations is that there is no significant removal of the "available" metal concentration up to L/S 10 in the column. These calculations, shown as dashed curves in Fig. 4, provide particular insight in the extent to which the predicted metal concentrations can be improved when the key parameters $\mathrm{pH}, \mathrm{FA}$ and HA are better predicted during transport. Fig. 4 shows that this model scenario indeed provides a better description of the $\mathrm{Cu}, \mathrm{Ni}, \mathrm{Cd}, \mathrm{Pb}$ and $\mathrm{Zn}$ concentrations, indicating that the reactive transport model requires improvement with respect to the prediction of $\mathrm{pH}, \mathrm{FA}$ and HA. It is emphasized that a model for the leaching of HA is not yet included in the reactive transport model as justified in the method Section 2.4.1, and discussed in Section 4.1 below.

The observed and predicted behaviour of the different metals will be explained below on the basis of calculated speciation diagrams. Fig. 6 includes calculated speciation diagrams based on the "dashed" model scenarios for the metals $\mathrm{Ni}, \mathrm{Cu}, \mathrm{Cd}, \mathrm{Pb}$ and $\mathrm{Zn}$ as shown in Fig. 4. The solution speciation is subdivided into "complexed with FA", "complexed 

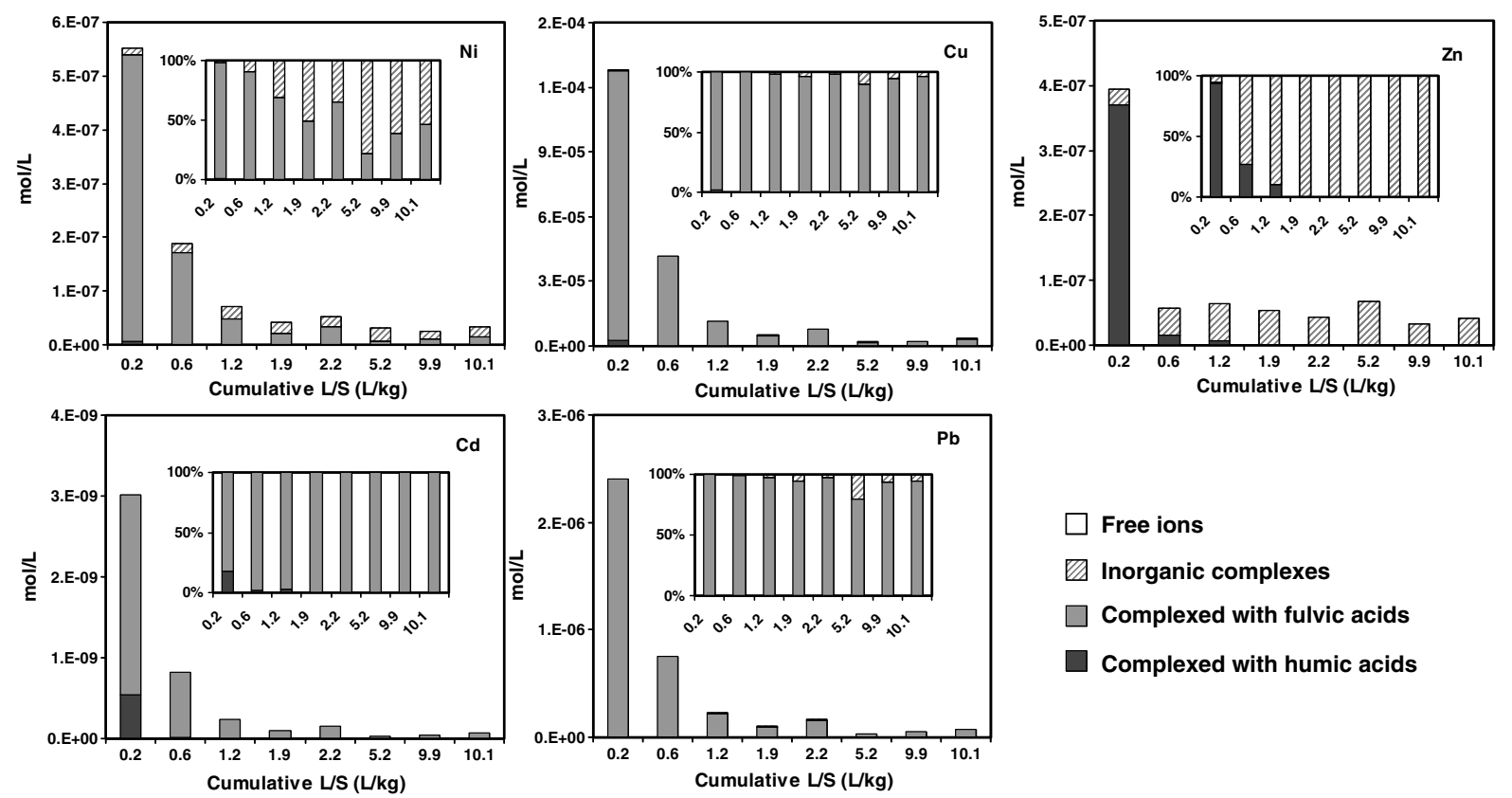

Fig. 6. Predicted solution speciation of $\mathrm{Ni}, \mathrm{Cu}, \mathrm{Cd}, \mathrm{Zn}$ and $\mathrm{Pb}$. The figure complements the predicted concentrations based on the model scenario indicated by the dashed curves in Fig. 4 (see Section 3.2.3.5).

with HA", "inorganic complexes" and "free ions" $\left(\mathrm{Me}^{2+}\right)$. The metals $\mathrm{Cu}, \mathrm{Cd}$ and $\mathrm{Pb}$ are predicted to be virtually $100 \%$ complexed to leached humic substances (FA and HA) over the full L/S range. The role of metal complexation by these humic substances is particularly pronounced at low $\mathrm{L} / \mathrm{S}$ ratios, where concentrations of FA and HA are highest. The strong overestimation of $\mathrm{Pb}$, in particular at low L/S, suggests that the solubility controlling processes for this metal are not sufficiently understood (see also Fig. 1). Initially, $\mathrm{Ni}$ is largely present as FA-Ni complexes, but at higher L/S ratio's, inorganic complexes form the dominant $\mathrm{Ni}$ species. This explains the predicted rather invariant concentrations of $\mathrm{Ni}$ towards higher $\mathrm{L} / \mathrm{S}$, while those of $\mathrm{Cu}$, $\mathrm{Cd}$ and $\mathrm{Pb}$ closely follow the continuously decreasing concentrations of FA. Leached $\mathrm{Zn}$ does not show significant interaction with $\mathrm{FA}$, but is predicted to form strong complexes with the low concentrations of HA in the first few fractions and, similar to $\mathrm{Ni}$, predominantly inorganic complexes towards higher $\mathrm{L} / \mathrm{S}$ ratios. In addition to $\mathrm{Zn}, \mathrm{Cu}$ and $\mathrm{Cd}$ are predicted to show significant interaction with the low concentrations of HA measured in the leachates.

The differences in predicted speciation between the metals are the result of different binding affinities for humic substances and the ability to form inorganic complexes, particularly at high $\mathrm{pH}$. For each metal separately, the speciation is also influenced by the relative difference in binding affinity for HA and FA (e.g., see the strong complexation of $\mathrm{Zn}$ with HA).

\section{Synthesis and conclusions}

\subsection{Characterization and modelling of processes}

The consistent "multi-surface" reactive transport modelling approach presented in this study leads to a strongly improved model prediction and understanding compared to previous reactive transport modelling studies performed on MSWI bottom ash (e.g., Bäverman et al., 1997; Yan et al., 1999; Dijkstra et al., 2002; Baranger et al., 2002; Gardner et al., 2002). Novel aspects of the present modelling approach include the characterization of DOC in terms of its reactive components $\mathrm{HA}$ and FA as a function of $\mathrm{L} / \mathrm{S}$ and $\mathrm{pH}$, the inclusion of mechanistic models that predict the binding of metals to these substances, the inclusion of a surface complexation model that predicts FA concentrations, and finally, the combination of these geochemical models with non-equilibrium processes. With the present model set-up and parameterization, the leaching of a broad range of major and trace elements is predicted gen- 
erally with success over a wide range of conditions (i.e., $\mathrm{pH} 2-12$ at $\mathrm{L} / \mathrm{S} 10$ and $\mathrm{L} / \mathrm{S} 0.2-10$ at natural $\mathrm{pH})$, with the same set of independently determined model input parameters in only two single model runs (i.e., a batch and a transport model run).

Although the combination of experimental and modelling results indicates that the leaching of major solubility-controlled elements occurs largely under local equilibrium conditions, this study has led to the identification of physical non-equilibrium processes for non-reactive soluble salts, as well as possible sorption-related non-equilibrium processes for the leaching of Mo, FA and associated trace metals. These processes are shown to become increasingly important for the understanding and prediction of element concentrations towards higher $\mathrm{L} / \mathrm{S}$ ratios (i.e., time periods). Therefore, the application of the present modelling approach to longterm field scenarios requires a careful examination and description of the hydrology (i.e., in terms of heterogeneous flow parameters) at the field site (e.g., Johnson et al., 1998; Johnson et al., 1999) and expressions for the non-equilibrium transport of FA. In addition, long-term model predictions for specific field-scale applications may require the model to be expanded with additional processes such as carbonation and redox reactions (see also CEN/TC292, 2006b; Kosson et al., 2002).

It should be noted that "equilibrium" with respect to the selected mineral assemblage in this study might not represent "true" thermodynamic equilibrium of the system as a whole (e.g., amorphous phases versus more stable crystalline phases). High temperature products such as MSWI bottom ash are almost by definition thermodynamically unstable, and subject to many dynamic changes such as weathering, including slow mineralogical alterations, and microbial processes (Zevenbergen and Comans, 1994, and references therein; Meima and Comans, 1997). Therefore, also a thermodynamically unstable mineral assemblage may control leaching in the laboratory and/or in the field during a certain time period.

Important input parameters in the modelling approach include the estimates for the "available" concentrations of major and trace elements. In this study pH 2 (metals) or 12 (anions) and L/S 10 extracts were successfully used for this purpose, assuming complete desorption/dissolution. This assumption is justified as close to $100 \%$ desorption and/or dissolution is predicted for most components at pH 2 (Figs. 1 and 2). However, a pH 2 extraction apparently leads to an underestimate of the availabilities of important the major elements $\mathrm{Al}$ and $\mathrm{Si}$ (Section 3.1). Moreover, it has been shown that extraction at a $\mathrm{pH}$ as low as 0.5 may be needed to estimate the availability of metals in organic rich systems such as soils (Dijkstra et al., 2004). Therefore, further research is necessary to develop a generic approach for the estimation of the "availability" of components in contaminated materials.

Given the predicted strong influence of FA as well as HA on the leaching of heavy metals, further improvement of the (reactive transport) modelling approach can particularly be achieved by a more mechanistic description of the (dynamic) leaching behaviour of these humic substances. Important new insights in the solid/solution partitioning of humic substances have been made by Filius et al. (2003) and Weng et al. (2002, 2006a,b). These developments are likely to contribute to further identification and modelling of the mechanisms controlling the leaching of these substances from soils and waste materials such as MSWI bottom ash.

\subsection{Implications for test settings and interpretation}

Within the boundaries of the investigated experimental conditions, both the cumulatively leached amounts after L/S 10 as well as concentrations in the individual fractions of the percolation test TS 14405 have been shown to be virtually insensitive to flow velocity. This important observation suggests that the currently prescribed "standard" flow velocity in TS 14405 is an adequate choice, at least in the case of MSWI bottom ash. Data from previous percolation tests on MSWI bottom ash (dating from 1998) performed at the standard, $4 \times$ faster and $4 \times$ lower flow velocity support these conclusions as no systematic difference in cumulatively leached concentrations could be identified (unpublished results; data available on request). However, the off-line measurements of leachate $\mathrm{pH}$ and possibly also other parameters from in particular the slowest experiment from the 1998 data set were biased by carbonation, complicating a process-based interpretation of the results. In particular at alkaline $\mathrm{pH}$, concentration-pH edges are extremely steep (e.g., see Ca in Fig. 2) and inaccuracies in the (off-line) measurement of $\mathrm{pH}$ by only tenths of a $\mathrm{pH}$-unit would strongly bias the identification of the processes controlling leaching. A lower flow velocity than "standard" is, therefore, not recom- 
mended as the longer time periods to collect a leachate fraction may induce such experimental artefacts. In any case, a careful preservation of the leachates as performed in this study is recommended to prevent interactions with the atmosphere (carbonation and/or oxidation).

The flow interruptions during and at the end of the experiments are at present not prescribed by TS 14405. Although these flow interruptions did not substantially contribute to the cumulatively leached amounts at L/S 10 , this procedure may be recommended to identify possible non-equilibrium conditions when these are suspected (see Brusseau et al., 1989). The currently prescribed initial equilibration period in TS 14405 is functional, as it promotes the levelling of concentration gradients after the column has been saturated with water. These gradients originate from the instantaneous dissolution of soluble salts travelling at the same velocity as the wetting front. As field residence times are much longer than column residence times, the initial equilibration period is expected to represent the actual leaching processes in the field more accurately (apart from density-driven flow that may occur in extreme salt-rich materials). In addition, the assumption of an initially homogeneous distribution of components over the column (Section 2.4.3) is better justified when the initial concentration gradients are levelled.

In conclusion, this study demonstrates that European standardized leaching test methods for waste materials (pH-dependent tests TS 14497/TS 14429, percolation test TS 14405) strengthen each other for the characterization of leaching processes in granular waste materials over a wide range of conditions that can be met in the field. As the modelling approach outlined in this study is based on the fundamental processes that underlie leaching, the approach is expected to be also applicable to other granular contaminated materials, application scenarios and conditions. Therefore, the combination of standardized leaching test methods, selective chemical extractions and mechanistic modelling, constitutes a promising generic approach to assess the long-term environmental impact of the application of granular contaminated materials in the environment.

\section{Acknowledgements}

This work was partially funded by basic funding from the Dutch Ministry of the Environment for the
Environmental Research Program of ECN. Esther Van der Weij-Zuiver, Petra Geelhoed-Bonouvrie and Remco Koper are greatly acknowledged for their careful experimental work. The authors thank Lydia Van Mourik for her helpful suggestions.

\section{References}

Allison, J.D., Brown, D.S., Novo-gradac, K.J., 1991. MINTEQA2/PRODEFA2, Geochemical assessment model for environmental systems: version 3.11 databases and version 3.0 user's manual. US-EPA, Environmental Research Laboratory, Athens, GA, USA.

Appelo, C.A.J., Postma, D., 2005. Geochemistry, second ed., Groundwater and Pollution Balkema, Rotterdam.

Appelo, C.A.J., Van Der Weiden, M.J.J., Tournassat, C., Charlet, L., 2002. Surface complexation of ferrous iron and carbonate on ferrihydrite and the mobilization of arsenic. Environ. Sci. Technol. 36, 3096-3103.

Baranger, P., Azaroual, M., Freyssinet, P., Lanini, S., Piantone, P., 2002. Weathering of a MSW bottom ash heap: a modelling approach. Waste Manage. 22, 173-179.

Bäverman, C., Sapiej, A., Moreno, L., Neretnieks, I., 1997. Serial batch tests performed on municipal solid waste incineration bottom ash and electric arc furnace slag in combination with computer modelling. Waste Manage. Res. 15, 55-71.

Blakemore, L.C., Searle, P.L., Daly, B.K., 1987. Methods for chemical analysis of soils. N.Z. Soil Bureau, Sci. Rep. 80, Lower Hutt, New Zealand.

Brookins, D.G., 1988. Eh-pH Diagrams for Geochemistry. Springer-Verlag, Berlin Heidelberg.

Brusseau, M.L., Rao, P.S.C., Jessup, R.E., Davidson, J.M., 1989 Flow interruption: a method for investigating sorption nonequilibrium. J. Contam. Hydrol. 4, 223-240.

CEN/TC292, 2004. Characterization of waste - Leaching behaviour tests - Up-flow percolation test (under specified conditions), CEN/TS 14405:2004.

CEN/TC292, 2006a. Characterization of waste - Leaching behaviour tests - Influence of $\mathrm{pH}$ on leaching with continuous pH-control. CEN/TS 14997:2006.

CEN/TC292, 2006b. Characterization of waste - Methodology for the Determination of the Leaching Behaviour of Waste under Specified Conditions. EN 12920:2006 (under approval).

Chandler, A.J., Eighmy, T.T., Hartlen, J., Hjelmar, O., Kosson, D.S., Sawell, S.E., Van der Sloot, H.A., Vehlow, J., 1997. Municipal Solid Waste Incinerator Residues. Elsevier Science B.V, Amsterdam, The Netherlands.

De Wit, J.C.M., 1992. Proton and metal ion binding by humic substances. PhD Thesis, Dept. Soil Quality, Wageningen University.

Dijkstra, J.J., Van der Sloot, H.A., Comans, R.N.J., 2002. Process identification and model development of contaminant transport in MSWI bottom ash. Waste Manage. 22, 531-541.

Dijkstra, J.J., Meeussen, J.C.L., Comans, R.N.J., 2004. Leaching of heavy metals from contaminated soils: an experimental and modeling study. Environ. Sci. Technol. 38, 4390-4395.

Dijkstra, J.J., Van der Sloot, H.A., Comans, R.N.J., 2006a. The leaching of major and trace elements from MSWI bottom ash as a function of $\mathrm{pH}$ and time. Appl. Geochem. 21, 335-351. 
Dijkstra, J.J., Van Zomeren, A., Meeussen, J.C.L., Comans, R.N.J., 2006b. Effect of accelerated aging of MSWI bottom ash on the leaching mechanisms of copper and molybdenum. Environ. Sci. Technol. 40, 4481-4487.

Dzombak, D.A., Morel, F.M.M., 1990. Surface Complexation Modeling: Hydrous Ferric Oxide. John Wiley \& Sons, Inc., New York.

Farley, K.J., Dzombak, D.A., Morel, F.M.M., 1985. A surface precipitation model for the sorption of cations on metal oxides. J. Colloid Interface Sci. 106, 226-242.

Filius, J.D., Lumsdon, D.G., Meeussen, J.C.L., Hiemstra, T., Van Riemsdijk, W.H., 2000. Adsorption of fulvic acid on goethite. Geochim. Cosmochim. Acta 64, 51-60.

Filius, J.D., Meeussen, J.C.L., Lumsdon, D.G., Hiemstra, T., Van Riemsdijk, W.H., 2003. Modelling the adsorption of fulvic acid by goethite. Geochim. Cosmochim. Acta 67, 14631474.

Gardner, K.H., Theis, T.L., Iyer, R., 2002. An experimental and analytical approach to understanding the dynamic leaching from municipal solid waste combustion residue. Environ. Eng. Sci. 19, 89-100.

Hiemstra, T., Van Riemsdijk, W.H., 2006. Biogeochemical speciation of Fe in ocean water. Mar. Chem. 102, 181-197.

Hiemstra, T., de Wit, J.C.M., Van Riemsdijk, W.H., 1989. Multisite proton adsorption modeling at the solid/solution interface of (hydr)oxides: a new approach, II. Application to various important (hydr)oxides. J. Colloid Interface Sci. 133, 105-117.

Johnson, C.A., Brandenberger, S., Baccini, P., 1995. Acid neutralizing capacity of municipal waste incinerator bottom ash. Environ. Sci. Technol., 142-147.

Johnson, C.A., Kersten, M., Ziegler, F., Moor, H.C., 1996. Leaching behaviour and solubility-controlling solid phases of heavy metals in municipal solid waste incinerator ash. Waste Manage. 16, 129-134.

Johnson, C.A., Richner, G.A., Vitvar, T., Schittli, N., Eberhard, M., 1998. Hydrological and geochemical factors affecting leachate composition in municipal solid waste incinerator bottom ash. Part I: The hydrology of landfill Lostorf, Switzerland. J. Contam. Hydrol. 33, 361-376.

Johnson, C.A., Kaeppeli, M., Brandenberger, S., Ulrich, A., Baumann, W., 1999. Hydrological and geochemical factors affecting leachate composition in municipal solid waste incinerator bottom ash. Part II: The geochemistry of leachate from landfill Lostorf, Switzerland. J. Contam. Hydrol. 40, 239-259.

Kinniburgh, D.G., Van Riemsdijk, W.H., Koopal, L.K., Borkovec, M., Benedetti, M.F., Avena, M.J., 1999. Ion binding to natural organic matter: competition, heterogeneity, stoichiometry and thermodynamic consistency. Colloids Surf. A 151, 147-166.

Koch, S., Fluhler, H., 1993. Non-reactive solute transport with micropore diffusion in aggregated porous media determined by a flow-interruption method. J. Contam. Hydrol. 14, 39-54.

Kosson, D.S., Van der Sloot, H.A., Sanchez, F., Garrabrants, A.C., 2002. An integrated framework for evaluating leaching in waste management and utilization of secondary materials. Environ. Eng. Sci. 19, 159-204.

Kostka, J.E., Luther III, G.W., 1994. Partitioning and speciation of solid phase iron in saltmarsh sediments. Geochim. Cosmochim. Acta 58, 1701-1710.
Lindsay, W.L., 1979. Chemical Equilibria in Soils. John Wiley \& Sons, New York.

Meeussen, J.C.L., 2003. ORCHESTRA: an object-oriented framework for implementing chemical equilibrium models. Environ. Sci. Technol. 37, 1175-1182.

Meima, J.A., Comans, R.N.J., 1997. Geochemical modelling of weathering reactions in MSWI bottom ash. Environ. Sci. Technol. 31, 1269-1276.

Meima, J.A., Comans, R.N.J., 1998. Application of surface complexation/precipitation modelling to contaminant leaching from weathered municipal solid waste incinerator bottom ash. Environ. Sci. Technol. 32, 688-693.

Meima, J.A., Comans, R.N.J., 1999. The leaching of trace elements from municipal solid waste incinerator bottom ash at different stages of weathering. Appl. Geochem. 14, 159171.

Milne, C.J., Kinniburgh, D.G., Van Riemsdijk, W.H., Tipping, E., 2003. Generic NICA-Donnan model parameters for metal-ion binding by humic substances. Environ. Sci. Technol. 37, 958-971.

Mostbauer, P., Lechner, P., 2006. Weathering of MSWI bottom ash in laboratory test cells and under field conditions - effect on metal and metalloid mobility. In: Proceedings of the 6th International Conference Environmental and Technical Implications of Construction with Alternative Materials, WASCON 2006, Belgrade, pp. 323-333.

NEN, 2003. Leaching characteristics - determination of the leaching of inorganic components from granular materials with a column test - Solid earthy and stony materials, NEN 7373:2003.

Piantone, P., Bodenan, F., Chatelet-Snidaro, L., 2004. Mineralogical study of secondary mineral phases from weathered MSWI bottom ash: implications for the modelling and trapping of heavy metals. Appl. Geochem. 19, 18911904.

Stumm, W., Morgan, J.J., 1981. Aquatic Chemistry, An Introduction Emphasizing Chemical Equilibria in Natural Waters. John Wiley \& Sons, Inc., New York.

Swift, R.S., 1996. Organic matter characterization. In: Sparks, D.L. (Ed.), Methods of Soil Analysis. Part 3. Chemical Methods. Soil Sci. Soc. Am., Madison, WI, USA, pp. 10111069.

Temminghoff, E.J.M., Van der Zee, S.E.A.T.M., De Haan, F.A.M., 1998. Effects of dissolved organic matter on the mobility of copper in a contaminated sandy soil. Eur. J. Soil Sci. 49, 617-628.

Thurman, E.M., Malcolm, R.L., 1981. Preparative isolation of aquatic humic substances. Environ. Sci. Technol. 15, 463-466.

Toride, N., Leij, F.J., Van Genuchten, M.T., 1999. The CXTFIT code for estimating transport parameters from laboratory or field tracer experiments, Version 2.1. Research report no. 137, US Salinity Laboratory, USDA, ARS, Riverside CA, USA.

US-EPA, 1999. MINTEQA2/PRODEFA2, A Geochemical assessment model for environmental systems: user manual supplement for version 4.0. National Exposure Research Laboratory, Ecosystems Research Division, Athens, GA, USA.

Van Genuchten, M.T., 1985. A general approach for modeling solute transport in structured soils. IAH Memoirs. 17, 513526.

Van Zomeren, A., Comans, R.N.J., 2004. Contribution of natural organic matter to copper leaching from municipal 
solid waste incinerator bottom ash. Environ. Sci. Technol. 38, 3927-3932.

Van Zomeren, A., Comans, R.N.J., 2007. Measurement of humic and fulvic acid concentrations and dissolution properties by a rapid batch procedure. Environ. Sci. Technol. 41, 6755-6761.

Weng, L., Temminghoff, E.J., Van Riemsdijk, W.H., 2002. Interpretation of humic acid coagulation and soluble soil organic matter using a calculated electrostatic potential. Eur. J. Soil Sci. 52, 587.

Weng, L., Van Riemsdijk, W.H., Hiemstra, T., 2006a. Adsorption free energy of variable-charge nanoparticles to a charged surface in relation to the change of the average chemical state of the particles. Langmuir 22, 389-397.

Weng, L.P., Van Riemsdijk, W.H., Koopal, L.K., Hiemstra, T., 2006b. Adsorption of humic substances on goethite: comparison between humic acids and fulvic acids. Environ. Sci. Technol. 40, 7494-7500.
Yan, J., Bäverman, C., Moreno, L., Neretnieks, I., 1999. Neutralising processes of municipal solid waste incineration bottom ash in a flow-through system. Sci. Total Environ. 227, $1-11$.

Zevenbergen, C., Comans, R.N.J., 1994. Geochemical factors controlling the mobilization of major elements during weathering of MSWI bottom ash. In: Goumans, J.J.J.M., Van der Sloot, H.A., Aalbers, Th.G. (Eds.), Studies in Environmental Science 60: Environmental Aspects of Construction with Waste Materials. Elsevier Science B.V, Amsterdam, The Netherlands, pp. 179-194.

Zevenbergen, C., Vander Wood, T., Bradley, J.P., Van der Broeck, P.F.C.W., Orbons, A.J., Van Reeuwijk, L.P., 1994. Morphological and chemical properties of MSWI bottom ash with respect to the glassy constituents. Hazard. Waste Hazard. Mater. 11, 371-383. 